\title{
Integration at a cost: Evidence from volatility impulse response functions
}

\author{
Ekaterini Panopoulou* Theologos Pantelidis ${ }^{\dagger}$
}

February 25, 2005

\begin{abstract}
We investigate the international information transmission between the U.S. and the rest of the G-7 countries using daily stock market return data covering the last 20 years. A pre-1995 and post1995 analysis reveals that the linkages between the markets have changed substantially in the more recent era, suggesting that national markets have become more interdependent. In the majority of the countries under scrutiny, we provide evidence of direct volatility spillovers, running mainly from the US and pointing to more rapid information transmission during the recent years. We further uncover the dynamics of the volatility spillovers between the international stock markets by means of a Volatility Impulse Response Analysis. Our findings, based on three historical shocks that have caused turbulence in the stock markets, suggest that the persistence of volatility shocks has increased substantially during the post-1995 period mainly due to increased persistence and interdependence in the volatility of all markets. As a result, volatility shocks in the international stock markets nowadays perpetuate for a significant longer period compared to the pre-1995 era.
\end{abstract}

JEL classification: $615, C 32$

Keywords: volatility spillovers, volatility impulse response functions, stock market, ARCH-BEKK

Acknowledgments: We are grateful to T. Flavin, C. Hafner and N. Pittis for helpful comments and suggestions. The authors thank the EU for financial support under the "PYTHAGORAS: Funding of research groups in the University of Piraeus" through the Greek Ministry of National Education and Religious Affairs. The usual disclaimer applies.

\footnotetext{
${ }^{*}$ Department of Banking and Financial Management, University of Piraeus, Greece and Department of Economics, National University of Ireland Maynooth. Correspondence to: Ekaterini Panopoulou, Department of Economics, National University of Ireland Maynooth, Co.Kildare, Republic of Ireland. E-mail: apano@nuim.ie. Tel: 0035317083793. Fax: 0035317083934.

${ }^{\dagger}$ Department of Banking and Financial Management, University of Piraeus, Greece.
} 


\section{Introduction}

In the wake of the stock market crash of October 1987, the study of the transmission of financial shocks across markets or countries has emerged as one of the most intensive research topics in the international finance literature in recent years. The first contributions in the so-called spillover literature came from Eun and Shim (1989) and Becker et al. (1990) who, based on either a VAR model or a set of single linear equations, tried to capture the dependence between international equity returns. In a similar way, Koch and Koch (1991) investigated the evolution of contemporaneous and lead/lag relationships among eight stock markets and concluded that regional interdependence grows over time and that the influence of the Japanese market increases at the expense of the US market. However, these studies focused on the return series and on how returns are correlated across markets, i.e. they considered only interdependence through the mean of the process.

A second strand of the literature, which is growing rapidly, explicitly focuses on the volatility of equity returns, suggesting the existence of higher-order dependence stemming from the second moments. This framework is appropriate when modeling high-frequency financial time series and its importance has been recognized ever since Engle (1982) introduced the class of ARCH models. In this context, Hamao et al. (1990) employed univariate GARCH models to examine the stock markets around the 1987 US stock market crash. They found evidence of significant price-volatility spillovers from the US to the UK and Japan and from the UK to Japan for the post-crash period. In contrast, no such spillovers are found in the pre-crash period. Their results suggest that shocks that originate in the US are larger and more persistent than the UK and Japanese ones. Lin et al. (1994), using a signal extraction model with GARCH processes, found a reciprocal relationship between the price and volatility of the US and Japanese markets. Susmel and Engle (1994) analyzed the interrelationship between the US and the UK stock markets using hourly returns and did not find strong evidence of either mean or volatility spillovers between the two markets. Karolyi (1995) examined the dynamic relationship between the US and Canadian stock market returns and return volatilities using a bivariate GARCH model. He found that the effects of shocks originating in the US market on the Canadian market returns and volatility are smaller and less persistent than those measured with traditional vector autoregressive models. Theodossiou 
and Lee (1993) studied the relationship between the US, the UK, Canadian, German and Japanese stock markets using a multivariate GARCH-in-mean model and found mean and volatility spillovers between some of those markets. The authors also documented that the US is the major exporter of volatility. More recently, Koutmos and Booth (1995) examined price volatility spillovers for the US, the UK and Japan in the context of an extensive multivariate Exponential GARCH model which can capture possible asymmetries in the volatility transmission mechanism. The authors found apart from price spillovers, extensive and reciprocal second moment interactions, which are asymmetric, i.e. negative innovations in a given market increase volatility in the next market to trade more than positive innovations. The appearance of the Asian financial crisis in 1997 revived the interest in the matter and turned the focus away from the major stock markets towards the emerging ones (see for example Ng, 2000; Caporale et al., 2001; He, 2001; Chen et al., 2002; Miyakoshi, 2003).

In this study, we focus explicitly on uncovering the volatility dynamics between the US stock market and the remaining six of the G-7 countries using Volatility Impulse Response Functions for multivariate GARCH models introduced by Hafner and Herwartz (2006). In this vein, we aim at establishing the pattern of information transmission between these countries. As indicated by Ross (1989), the transmission of information to a market is related primarily to the volatility of an asset's price changes in an arbitrage-free economy, i.e. the second moment is more important than the first one in the flow of information. In this vein, Engle et al. (1990) attribute movements in volatility to the lag with which market participants process new information.

The present study makes a twofold contribution. First, we estimate a bivariate GARCH model, for which a BEKK representation is adopted (see Engle and Kroner, 1995), for each of the six countries against the US using daily returns for the last twenty years. This BEKK formulation enables us to reveal the existence of any "meteor showers", i.e. transmission of volatility from one market to another, as well as any "heat waves", i.e. increased persistence in market volatility (see Engle et al., 1990). Splitting our sample into two non-overlapping sub-samples of equal length, we investigate whether the efforts for more economic, monetary and financial integration have fundamentally altered the sources and intensity of volatility spillovers to the individual stock markets. Second, by using a recently developed technique, we estimate the corresponding Volatility Impulse Response Functions (VIRFs) implied by the 
specification of each model. We then assess the impact of three historically observed shocks, i.e. the 1987 stock market crash, the 1997 Asian Financial crisis and the 2001 terrorist attack on the volatility and co-volatility of the markets.

To the best of our knowledge, no other study (except for Hafner and Herwartz, 2006) has employed this innovative technique of VIRFs to study volatility dynamics in any market. More importantly, there are several reasons why VIRFs represent a convenient approach to analyse volatility spillovers. First, this technique allows the researcher to determine precisely how a shock to one market influences the dynamic adjustment of volatility to another market and the persistence of these spillover effects. Second, VIRFs depend on both the volatility state and the unexpected returns vector when the shock occurs. As a result, the asymmetric response of volatility on negative and positive "news" typically documented in the literature (see e.g. Koutmos and Booth, 1995) can easily be accommodated. ${ }^{1}$ Third, contrary to typical Impulse Response Functions, this specific methodology avoids typical orthogonalization and ordering problems which would be hardly feasible in the case of highly interrelated and observed at high frequencies financial time series.

The only study that is closely related to ours is the one by Leachman and Francis (1996). The authors use a two-stage procedure, i.e. they first estimate univariate GARCH models for the G-7 stock market returns and then the estimated conditional variances are used to construct a VAR system. This methodology enables them to employ the standard Impulse Response analysis and conduct Variance Decompositions in order to determine how a shock to one market influences the dynamic adjustment of volatility in the remaining markets and the persistence of these volatility spillovers. They can also quantify the relative significance of each market in generating and transmitting fluctuations to other markets. Interestingly, the authors suggest that a multivariate GARCH approach would give more efficient parameter estimates than their two-stage approach but would not enable the researcher to obtain impulse response functions, as the latter are not available for GARCH processes.

It is this gap in the literature that we intend to bridge by estimating the VIRFs for the G-7 stock market returns accommodated by the aforementioned methodology. Consistent with the increased integration of capital markets already documented in the literature (see,

\footnotetext{
${ }^{1}$ Negative "news", i.e. unexpected returns, in one market can result in a different volatility profile than positive "news", other things being equal.
} 
for example, Harvey, 1991; Bekaert and Hodrick, 1992; Campbell and Hamao, 1992), our results suggest that equity markets have become more interdependent in the post-1995 period compared with the pre-1995 period. This greater integration resulted in a significant increase in the persistence of volatility shocks for all the countries at hand. The existence of both elevated "heat waves" and "meteor showers" effects is depicted in the pattern and size of the VIRFs.

The remainder of this study is organized as follows. Section 2 discusses the econometric methodology and Section 3 describes the data and presents the empirical findings for both the pre-1995 period and the post-1995 period. Section 4 offers a summary and some concluding remarks.

\section{Econometric Methodology}

In this section, we first present the model we employ to investigate the volatility spillovers between the stock markets under scrutiny and then provide a brief description of the volatility impulse response method employed to analyse the persistence of the volatility shocks in the international stock markets.

\subsection{The BEKK Model}

The analysis is based on a bivariate $\operatorname{VAR}(1)-\operatorname{GARCH}(1,1)$ model. Let $Y_{t}=\left(y_{1 t}, y_{2 t}\right)^{\prime}$ be the returns vector, with $y_{2 t}$ denoting the US stock market and $y_{1 t}$ one of the remaining G-7 countries. The conditional mean of the process is modeled as follows:

$$
Y_{t}=C+M * Y_{t-1}+E_{t}
$$

where $C$ is a $2 \times 1$ vector of constants and $M$ is a $2 \times 2$ coefficient matrix and $E_{t}=\left(e_{1 t}, e_{2 t}\right)^{\prime}$ is the vector of the zero-mean error terms. We allow $E_{t}$ to have a time-varying conditional variance, that is $\operatorname{Var}\left(E_{t} \mid \mathcal{F}_{t-1}\right)=H_{t}$ where $\mathcal{F}_{t-1}$ denotes the $\sigma$-field generated by all information available at time $t-1$. We further assume that the conditional variance, $H_{t}$, follows a bivariate $\operatorname{GARCH}(1,1)$ model and we, specifically, consider the following BEKK 
representation, introduced by Engle and Kroner (1995):

$$
\begin{gathered}
E_{t}=H_{t}^{1 / 2} * Z_{t} \\
H_{t}=\Omega * \Omega^{\prime}+A * E_{t-1} * E_{t-1}^{\prime} * A^{\prime}+B * H_{t-1} * B^{\prime}
\end{gathered}
$$

where $\Omega=\left[\omega_{i j}\right], i, j=1,2$ is a $2 \times 2$ lower triangular matrix of constants, $A=\left[a_{i j}\right]$ and $B=\left[b_{i j}\right], i, j=1,2$ are $2 \times 2$ coefficient matrices and $Z_{t}=\left(z_{1 t}, z_{2 t}\right)^{\prime} \sim i i d\left(\left[\begin{array}{l}0 \\ 0\end{array}\right],\left[\begin{array}{ll}1 & 0 \\ 0 & 1\end{array}\right]\right)$. Matrix $A$ measures the extent to which conditional variances are correlated with past squared unexpected returns (i.e. deviations from the mean) and consequently captures the effects of shocks on volatility. On the other hand, matrix $B$ depicts the extent to which current levels of conditional variances and covariances are related to past conditional variances and covariances. Apart from displaying sufficient generality, this model ensures that the conditional variance-covariance matrices, $H_{t}=\left[h_{i j, t}\right], i, j=1,2$, are positive definite under rather weak assumptions. $^{2}$

Compared to alternative multivariate GARCH representations, the BEKK model is more convenient for estimation, because it involves fewer parameters. Engle and Kroner (1995) prove that the BEKK model in (2) is second-order stationary if and only if all the eigenvalues of $(A \otimes A+B \otimes B)$ are less than unity in modulus. In this case, the unconditional variance of $E_{t}, \operatorname{Var}\left(E_{t}\right)$, can easily be calculated by: $\operatorname{vec}\left[\operatorname{Var}\left(E_{t}\right)\right]=\left[I_{4}-(A \otimes A)^{\prime}-(B \otimes B)^{\prime}\right]^{-1} * \operatorname{vec}\left(\Omega^{\prime} \Omega\right)$ where vec is the operator that stacks the columns of a square matrix. ${ }^{3}$

More in detail, the conditional variance for each equation can be expanded for the bivariate $\operatorname{GARCH}(1,1)$ as follows:

$$
\begin{aligned}
h_{11, t}= & \omega_{11}^{2}+a_{11}^{2} e_{1 t-1}^{2}+2 a_{11} a_{12} e_{1 t-1} e_{2 t-1}+a_{12}^{2} e_{2 t-1}^{2}+ \\
& +b_{11}^{2} h_{11, t-1}+2 b_{11} b_{12} h_{12, t-1}+b_{12}^{2} h_{22, t-1} \\
h_{22, t}= & \omega_{21}^{2}+\omega_{22}^{2}+a_{21}^{2} e_{1 t-1}^{2}+2 a_{21} a_{22} e_{1 t-1} e_{2 t-1}+a_{22}^{2} e_{2 t-1}^{2}+ \\
& +b_{21}^{2} h_{11, t-1}+2 b_{21} b_{22} h_{12, t-1}+b_{22}^{2} h_{22, t-1}
\end{aligned}
$$

\footnotetext{
${ }^{2}$ Engle and Kroner (1995) show that $H_{t}$ is positive definite if at least one of $\Omega$ or $B$ is of full rank.

${ }^{3}$ The moment properties of multivariate GARCH processes are also examined by Hafner (2003).
} 


$$
\begin{aligned}
h_{12, t}= & \omega_{11} \omega_{21}+a_{11} a_{21} e_{1 t-1}^{2}+\left(a_{11} a_{22}+a_{12} a_{21}\right) e_{1 t-1} e_{2 t-1}+a_{12} a_{22} e_{2 t-1}^{2}+ \\
& +b_{11} b_{21} h_{11, t-1}+\left(b_{11} b_{22}+b_{12} b_{21}\right) h_{12, t-1}+b_{12} b_{22} h_{22, t-1}
\end{aligned}
$$

Suppose that we estimate a bivariate system for Canada and the US based on equations (1) - (2). In such a case, $h_{11, t}$ and $h_{22, t}$ denote the conditional variance for Canada and the US respectively, while $h_{12, t}$ denotes the conditional covariance between the series. Significance of any or both the elements $a_{12}, b_{12}$ suggests that volatility in the Canadian market is affected by developments in the volatility of the US market through either the past volatility of the US market, $h_{22, t-1}$, or the past squared innovations $e_{2 t-1}^{2}$ (or even the cross products, $e_{1 t-1} e_{2 t-1}$, of past innovations). Furthermore, indirect feedbacks may exist through the past value of the conditional covariance $h_{12, t-1}$. When considering the evolution of the US market volatility and its dependence on the Canadian one, the reasoning is similar and follows directly from equation (4). The contemporaneous co-movement in the volatility of the series is given by equation (5) and is a function of past squared innovations, cross products of innovations, past conditional volatilities and naturally past conditional covariance. This rich parameterization suggests that even in the case that conditional volatilities between the series are not linked directly, i.e. $b_{12}=b_{21}=0$, the interactions between the conditional variances is ensured by past return innovations.

To cope with the excess kurtosis usually found in the estimated standardised residuals under the assumption of Gaussian innovations, we follow Bollerslev (1987) and evaluate (and maximize) the sample log-likelihood function under the assumption of $t(\nu)$ - distributed innovations. In such a case, given a sample of $T$ observations, a vector of unknown parameters $\theta$ and a $2 \times 1$ vector of returns $Y_{t}$, the bivariate BEKK model is estimated by maximizing the following likelihood function:

$$
L(\theta)=\sum_{t=1}^{T} \ln \left(l_{t}(\theta)\right)
$$

with

$$
l_{t}=\frac{\Gamma((T+v) / 2)}{\Gamma(v / 2)[\pi(v-2)]^{T / 2}}\left|H_{t}\right|^{-1 / 2}\left[1+\frac{1}{v-2} E_{t}^{\prime} H_{t}^{-1} E_{t}\right]^{-(T+v) / 2}
$$

where $\nu$ denotes the degrees of freedom of the $t$-distribution and $\Gamma(\cdot)$ is the gamma function. This log-likelihood function is maximized using the Berndt, Hall, Hall and Hausman (1974) 
algorithm (BHHH). ${ }^{4}$

\subsection{Volatility Impulse Response Functions}

We now briefly describe the Volatility Impulse Response Function (VIRF) introduced by Hafner and Herwartz (2006). The authors derive the VIRF based on an alternative multivariate GARCH representation, namely the vec-representation (introduced by Engle and Kroner, 1995), given by:

$$
\operatorname{vech}\left(H_{t}\right)=Q+R * \operatorname{vech}\left(E_{t-1} * E_{t-1}^{\prime}\right)+P * \operatorname{vech}\left(H_{t-1}\right)
$$

where $Q$ is a $3 \times 1$ matrix of constants, while $R$ and $P$ are $3 \times 3$ coefficient matrices. vech is the operator that stacks the lower triangular part of a square matrix. It is important to note that the vec-representation given in (8) requires the estimation of 21 parameters, while the BEKK representation given in (2) has only 11 parameters. Thus, the BEKK model manages to reduce substantially the number of parameters, facilitating the estimation procedure. Obviously, the vec-model is more general than the BEKK model, since the BEKK model reduces the number of parameters by imposing some specific restrictions on the vec-model. In general, any given BEKK model has a unique equivalent vec-representation (Engle and Kroner 1995), while the converse is not true. ${ }^{5,6}$ In summary, by employing the BEKK model we achieve the reduction of the number of parameters with virtually no cost in terms of the generality of the model. The derivation of the unique equivalent vec-representation of a BEKK model is straightforward. ${ }^{7}$ In the rest of this paper, we assume that (8) is the equivalent vec-representation of (2).

Assume that at time $t=0$ the conditional variance is at an initial state $H_{0}$ and an initial

\footnotetext{
${ }^{4}$ Susmel and Engle (1994) suggest that in the case of high-frequency financial data using the t-distribution generates a more efficient estimation for conditional errors than the normal distribution.

${ }^{5}$ Two GARCH representations are equivalent if every sequence of errors $\left\{E_{t}\right\}$ generates the same sequence of conditional volatilities $\left\{H_{t}\right\}$ for both representations.

${ }^{6} \mathrm{It}$ is possible that a vec-model has no equivalent BEKK representation. Moreover, if there is an equivalent BEKK representation for a vec-model, this BEKK representation is not unique.

$\left.\begin{array}{l}{ }^{7} \text { The necessary assumptions for the equivalence of the two representations are the following: } Q= \\ \omega_{11}^{2} \\ \omega_{11} \omega_{21} \\ \omega_{21}^{2}+\omega_{22}^{2}\end{array}\right], R=\left[\begin{array}{ccc}a_{11}^{2} & 2 a_{11} a_{12} & a_{12}^{2} \\ a_{11} a_{21} & a_{11} a_{22}+a_{12} a_{21} & a_{22} a_{12} \\ a_{21}^{2} & 2 a_{21} a_{22} & a_{22}^{2}\end{array}\right]$ and $P=\left[\begin{array}{ccc}b_{11}^{2} & 2 b_{11} b_{12} & b_{12}^{2} \\ b_{11} b_{21} & b_{11} b_{22}+b_{12} b_{21} & b_{22} b_{12} \\ b_{21}^{2} & 2 b_{21} b_{22} & b_{22}^{2}\end{array}\right]$.
} 
shock $Z_{0}=\left(z_{1,0}, z_{2,0}\right)^{\prime}$ occurs. The VIRF, $V_{t}\left(Z_{0}\right)$, is then defined as follows:

$$
V_{t}\left(Z_{0}\right)=E\left[\operatorname{vech}\left(H_{t}\right) \mid \mathcal{F}_{t-1}, Z_{0}\right]-E\left[\operatorname{vech}\left(H_{t}\right) \mid \mathcal{F}_{t-1}\right]
$$

The first and third elements of $V_{t}\left(Z_{0}\right)$ (denoted as $v_{1, t}$ and $v_{3, t}$ respectively) represent the reaction of the conditional variance of the first and second variable respectively to the shock, $Z_{0}$, that occurred $t$ periods ago. Similarly, the second element of $V_{t}\left(Z_{0}\right)$ (denoted as $v_{2, t}$ ) represents the reaction of the conditional covariance to the shock, $Z_{0}$, that occurred $t$ periods ago. The VIRF can easily be computed recursively based on the following relations:

$$
\begin{aligned}
& V_{1}\left(Z_{0}\right)=R *\left\{\operatorname{vech}\left(H_{0}^{1 / 2} Z_{0} Z_{0}^{\prime} H_{0}^{1 / 2}\right)-\operatorname{vech}\left(H_{0}\right)\right\} \\
& V_{t}\left(Z_{0}\right)=(R+P) * V_{t-1}\left(Z_{0}\right), t>1
\end{aligned}
$$

The VIRF has two important differences compared to the traditional Impulse Response Function (IRF) in the conditional mean. First, the VIRF is an even function of the initial shock, that is $V_{t}\left(Z_{0}\right)=V_{t}\left(-Z_{0}\right)$, contrary to the IRF that is an odd function of the initial shock. Second, the IRF is a linear function, i.e. $\operatorname{IRF}\left(k * Z_{0}\right)=k * \operatorname{IRF}\left(Z_{0}\right)$, while the VIRF is not homogeneous of any degree.

Before presenting the empirical results of this study, we briefly describe the behavior of the VIRF. First of all, let $\Psi=\left[\psi_{i, 1}\right]:=\operatorname{vech}\left(H_{0}^{1 / 2} Z_{0} Z_{0}^{\prime} H_{0}^{1 / 2}\right)-\operatorname{vech}\left(H_{0}\right)$ where $i=1,2,3$. It is obvious that the elements of $\Psi$ are functions of the elements of the initial state $H_{0}$ and the elements of the shock $Z_{0}$. The following three cases are of interest:

Case I: Diagonal BEKK model (i.e. $a_{12}=a_{21}=b_{12}=b_{21}=0$ )

In this case, both $R$ and $P$ (and thus $R+P$ ) are diagonal matrices (see footnote 7 ). It is easy to show that:

$$
\begin{aligned}
& v_{1,1}=a_{11}^{2} \psi_{1,1} \text { and } v_{1, t}=\left(a_{11}^{2}+b_{11}^{2}\right)^{t-1} v_{1,1} \text { for } t>1 \\
& v_{2,1}=a_{11} a_{22} \psi_{2,1} \text { and } v_{2, t}=\left(a_{11} a_{22}+b_{11} b_{22}\right)^{t-1} v_{2,1} \text { for } t>1 \\
& v_{3,1}=a_{22}^{2} \psi_{3,1} \text { and } v_{3, t}=\left(a_{22}^{2}+b_{22}^{2}\right)^{t-1} v_{3,1} \text { for } t>1
\end{aligned}
$$

Therefore, in this particular case there are no volatility spillovers, since both $v_{1, t}$ and $v_{3, t}$ 
depend only on their own history. It is important to note that in this case of a diagonal BEKK model, the half-life of a volatility shock is independent of both the initial shock, $Z_{0}$ and the initial state $H_{0}{ }^{8}$

Case II: $a_{12}=b_{12}=0$, while $a_{21} \neq 0$ and $/$ or $b_{21} \neq 0$

In this case, both $R$ and $P$ (and thus $R+P$ ) are lower triangular matrices. Therefore,

$$
\begin{aligned}
& v_{1,1}=a_{11}^{2} \psi_{1,1} \text { and } v_{1, t}=\left(a_{11}^{2}+b_{11}^{2}\right)^{t-1} v_{1,1} \text { for } t>1 \\
& v_{2,1}=a_{11} a_{21} \psi_{1,1}+a_{11} a_{22} \psi_{2,1} \text { and } v_{2, t}=f\left(v_{1,1}, v_{2,1}\right) \text { for } t>1 \\
& v_{3,1}=a_{21}^{2} \psi_{1,1}+2 a_{21} a_{22} \psi_{2,1}+a_{22}^{2} \psi_{3,1} \text { and } v_{3, t}=g\left(v_{1,1}, v_{2,1}, v_{3,1}\right) \text { for } t>1
\end{aligned}
$$

where $f$ is a function of $v_{1,1}, v_{2,1}, a_{i j}$ and $b_{i j}, i . j=1,2$ and $g$ is a function of $v_{1,1}, v_{2,1}$, $v_{3,1}, a_{i j}$ and $b_{i j}, i . j=1,2 .{ }^{9}$ It is clear that in this particular case there are unidirectional volatility spillovers from the first to the second variable of the system. Consequently, the effect of the shock on the conditional variance of the first variable of the system does not depend on the behavior of the second variable of the system. We should note that even if $a_{21}=0$ or $b_{21}=0$, there are still volatility spillovers from the first to the second variable of the system. Finally, in this particular case, the half-life of a volatility shock in $h_{11, t}$ is independent of the initial shock, $Z_{0}$ and the initial state $H_{0}$, while the half-life of a volatility shock in $h_{22, t}$ and $h_{12, t}$ depends on both the initial shock, $Z_{0}$. and the initial state $H_{0}$.

Case III: $a_{12} \neq 0$ and/or $b_{12} \neq 0$, while $a_{21} \neq 0$ and/or $b_{21} \neq 0$

In this general case, it is easy to verify that bidirectional volatility spillovers exist between the variables of the system.

\section{Empirical Results}

\subsection{Data}

Our dataset comprises daily closing stock market indices from the stock exchanges of the G-7 countries: (1) S\&P/TSX Index (Canada), (2) CAC 40 Index (France), (3) DAX 30 Index (Germany), (4) BCI Index (Italy), (5) NIKKEI 225 (Japan), (6) FTSE 100 Index

\footnotetext{
${ }^{8}$ We define the half-life of a volatility shock to be the time required for the impact of the shock to reduce to half its maximum value.

${ }^{9}$ For example, $f\left(v_{1,1}, v_{2,1}\right)=\frac{\left(a_{11} a_{21}+b_{11}+b_{21}\right)\left[\left(a_{11}^{2}+b_{11}^{2}\right)^{t-1}-\left(a_{11} a_{22}+b_{11} b_{22}\right)^{t-1}\right]}{a_{11}^{2}-a_{11} a_{22}+b_{11}\left(b_{11}-b_{22}\right)} v_{1,1}+\left(a_{11} a_{22}+b_{11} b_{22}\right)^{t-1} v_{2,1}$.
} 
(UK) and (7) S\&P 500 Index (US). The indices span a period of approximately 20 years from 31/12/1985 to 08/10/2004, a total of 4896 observations. All stock indices, obtained from EcoWin, are expressed in US dollars. This denomination of the series in US dollars suggests that the analysis is conducted from the point of view of a US investor facing the remaining G-7 equity markets as foreign ones. Moreover, we prefer daily return data to lower frequency data, such as weekly and monthly returns, because longer horizon returns can obscure transient responses to innovations which may last for a few days only. ${ }^{10}$ For each index, we compute the return between two consecutive trading days, $t-1$ and $t$ as $\ln \left(p_{t}\right)-\ln \left(p_{t-1}\right)$ where $p_{t}$ denotes the closing index on day $t$. We conduct our analysis for two non-overlapping subsamples of approximately equal length. The first subsample ends at 31/12/1994. Table 1 reports the descriptive statistics of stock returns for the samples under consideration. Panel A reports the statistics for the full sample, while Panels B and C refer to the two subperiods considered, namely the pre-1995 and the post-1995 period.

The UK stock market consistently yields the highest daily returns for the periods under consideration, although during the post-1995 subperiod, it is closely followed by the US and Canada market. The worst performance in terms of daily returns is Japan's over the full sample and the second subperiod. Notably, in the post-1995 period, Japan is the only country with negative daily returns. Volatility (as measured by the standard deviation of the return series) is higher in Japan followed by Germany. A comparison between the two sub-samples suggests that there are no significant differences in the volatility of the series. A visual perspective of the volatility of the series at hand can be gained from the plots of daily returns for each series in Figure 1. Moreover, all the distributions seem to exhibit asymmetries and fat tails with relation to the Normal distribution. All the markets have negative skewness, with the exception of Japan for the full and post-1995 periods. Skewness is higher, in absolute terms, during the pre-1995 era reflecting the effects of the 1987 crash. As expected, the highest skewness is related to the US, the country from which the crash originated. Fat tails, as depicted in the kurtosis of the distribution, are also more prominent in the US followed by Canada and the UK. In any case, the distribution of the return series suffers from serious departures from the Gaussian distribution. Furthermore, these

\footnotetext{
${ }^{10}$ Eun and Shim (1989) and Karolyi and Stulz (1996) suggest that high-frequency data (even intra-day) are more practical for studying international correlations or spillovers than low-frequency ones.
} 
descriptive statistics show that the nature of the data varies significantly between the two sub-samples, justifying our modeling strategy.

\subsection{Bivariate Volatility Dynamics}

We estimate a bivariate GARCH-BEKK model for each country against the US. Our choice of the US as the country against which all volatility dynamics are modeled stems from the price leader role of the US equity market. Since the US economy dominates the world economy and trade, it is natural to expect the existence of economic and financial relationships with the rest of the world. As a result, information about the US economic fundamentals and equity market developments are transmitted all over the world and have a significant impact on world-wide stock markets. ${ }^{11}$ Furthermore, the US capital market is by far the largest capital market in the world, accounting for approximately half the world market capitalization. Japan and the UK account for $13 \%$ and $9.3 \%$ of the world market, while the respective figures for the remaining G7 countries range from $2 \%$ to $4 \%{ }^{12}$

Turning to the estimation procedure, we use univariate $\operatorname{GARCH}(1,1)$ estimates for every series at hand as initial values for the estimation of the BEKK model. Diagonal elements of the matrices $A$ and $B$ are taken to be the square root of the corresponding univariate estimates, while the off-diagonal elements of $A$ and $B$ are initialised to zero. As aforementioned the estimation of the BEKK model is performed under the assumption that the conditional distribution of the innovations is $t$ with $v$ degrees of freedom, which are also estimated through the maximization of the log-likelihood function as defined in equations (6) and (7) by means of the $\mathrm{BHHH}$ algorithm. The estimated parameters of the conditional variances and covariances with associated standard errors, the estimated degrees of freedom from the $t$-distribution, the likelihood function values along with the eigenvalues of the whole system are given in Table 2 (Panels A-B). Panel A refers to the pre-1995 period, while the results for the post-1995 period are reported in Panel B. Having as a starting point the estimated unrestricted models, we proceed in restricting our models based on a General-to-Specific methodology, i.e. re-estimating our model by dropping the least significant coefficient at a time. The results from the estimated restricted models are reported in Table 3 (Panels A

\footnotetext{
${ }^{11}$ Many studies have provided supportive evidence in favor of the US price leadership. See e.g. Eun and Shim (1989), Hamao et al. (1990), Theodossiou and Lee (1993) and Lin et al. (1994).

${ }^{12}$ See Flavin et al. (2002).
} 
and B for the pre-1995 and post-1995 periods respectively).

We, then, use the Likelihood Ratio test to establish the validity of the zero restrictions imposed in the restricted models. More specifically, the LR statistic is defined as follows

$$
L R-s t a t=-2\left(\log l_{r e}-\log l_{u n}\right)
$$

where $\log l_{r e}$ and $\log l_{u n}$ refer to the maximum value of the $\log$-likelihood function for the restricted and the unrestricted models respectively. Under the null hypothesis the zero restrictions are valid and thus the restricted model is preferable compared to the unrestricted one. We should note that since the distribution of (10) under the null depends on nuisance parameters, we cannot claim that the $L R$-stat follows asymptotically a $X^{2}(k)$ distribution where $k$ equals to the number of restrictions imposed in the restricted model. However, simulation results reported in previous studies (see Caporale et al., 2001) reveal that the test performance improves considerably as the sample size increases, requiring $T \succeq 3000$ for empirical rejection frequencies to approximate the nominal significance level. In our case, we have about 2500 observations in each subsample and thus we consider the use of the $X^{2}(k)$ distribution for the $L R-$ stat to be meaningful.

The estimated values of the $L R$ - stat for all the pairs of countries are reported in Table 4. Notably, the null hypothesis of a restricted model versus the unrestricted one cannot be rejected for any country for both the samples under consideration. The largest estimated value of the $L R$ - stat is 11.21 with a corresponding p-value of $19 \%$ (based on the $X^{2}(8)$ distribution). ${ }^{13}$

To facilitate the discussion, we only comment on the results from the selected models, i.e. the restricted ones and mainly focus on comparing the results from the two sub-periods. On the whole, the conditional variance-covariance equations incorporated in the GARCHBEKK methodology effectively capture the volatility and cross volatility dynamics among the markets under consideration. Therefore, useful insights are provided as far as the changes in volatility linkages among the US and the rest of the G-7 countries are concerned.

Starting with Canada, France and Germany, we find that volatility (conditional variance)

\footnotetext{
${ }^{13}$ Note that the degree of freedom includes restrictions in both the conditional mean and the conditional variance of the process. The estimated mean equations are not reported, since our focus is on the second-order moments. All the results are available upon request.
} 
in these countries is directly affected by the US volatility in both periods under examination, while no evidence of the opposite effect is present. In the case of Canada, volatility is transmitted through the US volatility in the pre-1995 period, while in the post-1995 period volatility spillovers are transmitted through the cross product of innovations and squared US innovations as well. Turning to France, the results are similar to the case of Canada, i.e. no transmission of volatility is prevalent from the French to the US stock market in either sub-sample. Positive feedbacks from the US volatility are transmitted through the product of innovations of the two markets and the US squared innovations during the first subsample, while through the US volatility during the more recent period. In this sense, more intense volatility spillovers are expected during the post-1995 period and milder ones during the pre1995 one, mainly due to the persistence of the US volatility. The next European market, the German one, is found to react in a similar way with volatility feedbacks occurring through the cross products of innovations and squared innovations of the US market in both subperiods. On the whole, our findings for these countries are consistent with the notion that these are too small to have a significant influence on the volatility dynamics of the US market.

The same holds for the Italian market, which exhibits a considerable degree of volatility independence during the pre-1995 period, when the only channel of volatility transmission seems to be the indirect one through the conditional covariance of the Italian with US returns. Our findings for the post-1995 period suggest that the Italian market has become more integrated and consequently, more responsive to shocks originating in the US. Specifically, shocks hitting the US market have a significant positive effect on the Italian volatility.

Contrary to the aforementioned countries, the Japanese and UK stock markets paint a whole different picture. The behavior of the conditional variances of the series are starkly different in the periods under examination. During the pre-1995 period, no cross-market dependencies are apparent, as indicated by the diagonality of the corresponding BEKK models. However, our estimates for the second subperiod support the increased integration of both markets with the US stock market, allowing for bidirectional volatility transmission. Specifically, positive feedbacks are transmitted from the US stock volatility to the Japanese volatility, while negative ones are transmitted in the opposite direction. Turning to the UK, volatility transmission is likely to be more intense from the US to the UK than in the opposite direction, since the transmission channel in this case is both through cross-innovations and 
past US volatility.

In general, our results corroborate and extend the results of Hamao et al. (1990), Lin et al. (1994), Cheung and Ng (1996), Leachman and Francis (1996) and other authors. However, all these studies were performed prior to 1996 and consequently their results are comparable to our pre-1995 period results. A direct comparison of our results concerning the post-1995 period to previous studies is not feasible as we are not aware of any recent study on volatility spillovers for the developed countries.

More importantly, our estimates of the eigenvalues of the BEKK models (reported in Table 3) suggest that volatility has become more persistent in the recent years, indicating that the duration of volatility spillovers is likely to increase. Earlier findings by Billio and Pelizzon (2003) and other studies have pointed to increased persistence in the equity returns volatility. ${ }^{14}$ This change in the volatility persistence along with the change in volatility linkages is directly related to the pattern of the impulse response functions presented in the next section.

\subsection{Estimates of Volatility Impulse Response Functions}

In this subsection we examine the persistence of volatility shocks in the stock market returns by means of the volatility impulse response function (VIRF) described in subsection 2.2. Instead of considering a set of random (and probably controversial) volatility shocks, we investigate three observed historical shocks. In this way, the analysis is realistic and provides useful insights with respect to the size and persistence of volatility spillovers in the international stock markets in the event of a similar crisis. As a measure of the intensity of the volatility spillover, we calculate the half-life of a shock, i.e. the time period (in days) required for the impact of the shock to reduce to half its maximum value. Our analysis is confined to the two sub-periods under scrutiny, in order to reveal possible changes in the persistence of volatility shocks.

The first historical shock considered in our study is the 1987 stock market crisis. We first calculate the initial shock, $\widehat{Z}_{0}$, on the basis of the estimated restricted models given in Panel A of Table 3. Specifically, on October 19, 1987, the estimated residual vector, $\widehat{E}_{t}$, and the estimated volatility state, $\operatorname{vech}\left(\widehat{H}_{t}\right)$, were $(-0.1162,-0.2295)^{\prime}$ and $\left(0.562 \times 10^{-4}, 0.764 \times\right.$

\footnotetext{
${ }^{14}$ The authors, using a switching regime beta model, find an increase in the world volatility for the post-1997 period, even for tranquil periods.
} 
$\left.10^{-4}, 2.03 \times 10^{-4}\right)^{\prime}$ respectively for the Canada-US model, In this case, the initial shock is estimated to be $\widehat{Z}_{0}=\left(\widehat{H}_{t}^{1 / 2}\right)^{-1} \widehat{E}_{t}=(-9.74,-14.04)^{\prime}$. The corresponding initial shocks for the remaining five models are calculated in a similar way.

The second shock we consider is the Asian financial crisis in 1997. More specifically, we calculate the initial shock based on the estimated models (Table 3, Panel B) for October 27, 1997. The last shock we consider is the one associated with the terrorist attack to the Twin Towers in September 2001. Since the first trading day for the US stock market after the attack was the September 17, 2001, the initial shocks are calculated based on this day. The estimated initial shocks for these three historical shocks with respect to our estimated models are reported in Table 5 .

Apart from the estimated parameters of the BEKK models and the corresponding initial shocks, the calculation of the VIRFs requires the initial state of volatility, $H_{0}$, as suggested by equation (9). To make our findings invariant to the choice of initial state, we select the last day of our sample, i.e. October 8, 2004 and employ this estimated conditional variancecovariance matrix in both sub-periods. ${ }^{15}$ This allows a direct comparison of the VIRFs between the two sub-periods under consideration.

We first investigate the size of the effect of each shock on the conditional variance of the series under examination. Table 7 reports the maximum value and the 1 -step ahead value of the VIRF divided by the initial conditional variance. As expected, the effect of the 1987 crash on the conditional volatility dynamics is substantially greater than the corresponding effects stemming from the other two shocks considered in this analysis. For example, in the case of the US, the crash of 1987 induces a rise in volatility that is 6.57 and 17.18 times the initial volatility for the pre-1995 and post-1995 period respectively. ${ }^{16}$ The corresponding figures for the Asian financial crisis are 1.06 and 2.78 for the periods examined. Even milder effects are prevalent when the third shock is considered. ${ }^{17}$

The increased intensity of volatility spillovers during the recent years is easily shown when

\footnotetext{
${ }^{15}$ The initial states employed for each pair of countries are presented in Table 6. Alternatively, the estimated unconditional variance matrix of $E_{t}$ could be employed as an initial state. In such a case, our results would be qualitatively similar to the ones reported.

${ }^{16}$ The analysis for the US is based on the Canada-US model, although quantitatively similar results are drawn from the rest of the bivariate models.

${ }^{17}$ In this case, if a similar shock occurred in the pre-1995 period, the increase in the US volatility would be just 0.53 times the initial volatility, while in the case of the post-1995 period, the volatility increase would be 1.38 times the initial volatility.
} 
the path of the impulse responses in the volatility of each country is considered. Figures 2-4 plot the VIRFs for the three shocks respectively. In most cases, the VIRF is maximised the day after the shock. However, in some cases the effect of the initial shock gradually increases, reaching its maximum value after many days or even weeks. In general, the impulses are declining starting from a high level of volatility. In some cases, however, there is evidence of an initial shock amplification which increases further the initial effect. Eventually, in all cases the VIRFs resume their declining path towards zero.

We now focus on the estimated half-life of the volatility shocks, which are reported in Table 8 (Panels A, B and C for the three shocks respectively) for all six pairs of countries and the two sub-periods. ${ }^{18}$ Apparently, the half-lives of volatility shocks paint a similar picture pointing to more persistent shocks in the more recent era. For example, for the pre-1995 period and for the 1987 crash, the estimated half-lives for the US, the country from which the crash originated, range from 48 to 91 days, while if the shock occurred in the post-1995 period, the respective figures would be 98 days to 219 days. The half-lives for the rest of the countries are lower than the US in the first sub-period ranging from 13 days (UK and France) to 41 days (Japan). Surprisingly, our findings from the recent era suggest that a similar to the "1987 crash" shock would induce volatility spillovers that would last for significantly longer period nowadays compared to the pre-1995 period. Our results for the other two shocks are qualitative similar to those of the first shock, so we do not discuss them separately to save space.

In summary, the empirical findings of this volatility impulse response experiment suggest that the increased integration of the international stock markets during the post-1995 period has also caused an increase in the persistence of volatility shocks. As a result, similar volatility shocks can perpetuate for a significant longer period nowadays compared to the pre-1995 era.

\section{Conclusions}

There is extensive empirical work in the literature with respect to interdependencies between financial markets and more specifically, national stock markets. This paper focuses on second-

\footnotetext{
${ }^{18}$ Note that the half-lives in Table 8 are calculated after the Initial Shock Amplification has been deducted.
} 
order interdependencies, i.e. linkages through the conditional variances of the series. The analysis was performed using daily closing stock index data from the G-7 stock markets for the last 20 years. By adopting a bivariate BEKK representation and splitting our sample into two 10-year sub-samples, we first examined whether stock market linkages between the US and the remaining of the G-7 countries have changed during the recent years. As a second step, we employed a new technique developed by Hafner and Herwartz (2006) and estimated the Volatility Impulse Response Functions (VIRFs) related to each pair of our countries. This technique enabled us to quantify the size and the persistence of three historical shocks that have caused turbulence in the stock markets. Furthermore, the significantly different structure of stock markets in the pre- and post-1995 periods allowed comparisons that shed some light into the current behavior of stock markets.

Our empirical findings can be summarised as follows. We confirmed the established view that the US stock market is the major volatility exporter country. Specifically, there is evidence of significant volatility spillovers from the US to Canada, France and Germany during the pre-1995 period. For the same period, the rest of the G-7 countries, i.e. Italy, Japan and the UK appear secluded and invulnerable to shocks originating in the US. On the other hand, our findings for the more recent period point to increased integration between the markets. Specifically, the smaller of the G-7 countries, i.e. Canada, France, Germany and Italy mainly import volatility from the US. A more important finding, however, is the evidence in favor of bidirectional volatility spillovers between the US and Japan, as well as the US and the UK. Our results suggest that shocks originating in the UK affect positively the US stock market while the Japanese ones influence the US market negatively, inducing lower levels of volatility. Our VIRFs analysis of three historical shocks, namely the 1987 crash, the 1997 Asian financial crash and the 2001 terrorist attack provided useful insights with respect to the size and persistence of volatility shocks. We specifically found evidence in favor of increased amplitude and duration of volatility spillovers in the post-1995 sample compared to the pre-1995 one. This intensity of shocks mainly stems from the increased interdependence and persistence of the equity market volatilities documented in the recent era. Consequently, had a shock similar to the one of the 1987 crash occurred in the more recent years, the time required for this shock to die out would have been extremely longer nowadays compared to the pre-1995 period. 
The method employed here can also be applied to other cases that involve high frequency data, mainly financial data, to examine linkages and uncover the volatility dynamics between the series under examination. Volatility spillovers between exchange rate markets or between stock markets and exchange rates can be detected and quantified through the VIRFs. Another promising route for further investigation may be the extension of this bivariate analysis to a higher order one, allowing for interactions among three or more countries. Both these extensions will be the object of our future work.

\section{References}

[1]Becker, K.G., J.E. Finnerty and M. Gupta (1990). The intertemporal relation between the U.S. and Japanese stock markets. Journal of Finance, 45, 1297-1306.

[2]Bekaert, G. and R.J. Hodrick (1992). Characterizing predictable components in excess returns on equity and foreign exchange markets. Journal of Finance, 47, 467-470.

[3]Berndt, E.K., B.H. Hall, R.E. Hall and J.A. Hausman (1974). Estimation and inference in non-linear structural models. Annals of Economic and Social Measurement, 69, 542-547.

[4]Billio, M. and L. Pelizzon (2003). Volatility spillovers before and after EMU in European stock markets. Journal of Multinational Financial Management, 13, 323-340.

[5]Bollerslev, T. (1987). A conditional heteroskedastic time series model for speculative prices and rates of return. Review of Economics and Statistics, 69, 542-547.

[6]Campbell, Y. and Y. Hamao (1992). Predictable stock returns in the United States and Japan: A study of long-term capital market integration. Journal of Finance, 47, 43-69.

[7]Caporale, G.M., N. Pittis and N. Spagnolo (2001). Volatility transmission and financial crises. DP02-2001, Centre for Monetary and Financial Economics, South Bank University, London, forthcoming at the Journal of Economics and Finance.

[8]Chen, G., M. Firth and O.M. Rui (2002). Stock market linkages: Evidence from Latin America. Journal of Banking and Finance, 26(6), 1113-1141. 
[9]Cheung Y.M. and L.K. Ng (1996). A causality-in-variance test and its application to financial market prices. Journal of Econometrics, 72, 33-48.

[10]Engle, R.F. (1982). Autoregressive conditional heteroskedasticity with estimates of the variance of U.K. inflation. Econometrica, 50, 987-1008.

[11]Engle, R.F., T. Ito and W.L. Lin (1990). Meteor showers or heat wages? Heteroskedastic intra-daily volatility in the foreign exchange market. Econometrica, 58, 525-542.

[12]Engle, R.F. and K.F. Kroner (1995). Multivariate simultaneous generalized ARCH. Econometric Theory, 11, 122-150.

[13]Eun, C. and S. Shim (1989). International transmission of stock market movements. Journal of Financial and Quantitative Analysis, 24, 241-256.

[14]Flavin T., M. Hurley and F. Rousseau (2002). Explaining stock market correlation: A gravity model approach. The Manchester School, 70, 87-106.

[15]Hafner, C.M. (2003). Fourth moment structure of multivariate GARCH models. Journal of Financial Econometrics, 1, 26-54.

[16]Hafner, C. and H. Herwartz (2006). Volatility Impulse Response Functions for Multivariate GARCH Models: An Exchange Rate Illustration. Journal of International Money and Finance, forthcoming.

[17]Hamao, Y., R. Masulis and V. Ng (1990). Correlations in price changes and volatility across international stock markets. Review of Financial Studies, 3, 281-307.

[18]Harvey, R. (1991). The world price of covariance risk. Journal of Finance, 46, 111-158.

[19]He, L.T. (2001). Time variation paths of international transmission of stock volatility US vs. Hong Kong and South Korea. Global Finance Journal, 12(1), 79-93.

[20]Karolyi, A. (1995). A multivariate GARCH model of international transmission of stock returns and volatility. Journal of Business, Economics and Statistics, 13, 11-25.

[21]Karolyi, A. and R.M. Stulz (1996). Why do markets move together? An investigation of US-Japan stock return comovements. Journal of Finance, 51, 951-986. 
[22]Koch, P.D. and T.W. Koch (1991). Evolution in dynamic linkages across daily national stock indexes. Journal of International Money and Finance, 10, 231-251.

[23]Koutmos, G. and G.G. Booth (1995). Asymmetric volatility transmission in international stock markets. Journal of International Money and Finance, 14, 747-762.

[24]Leachman, L.L. and B. Francis (1996). Equity market return volatility: Dynamics and transmission of the G-7 countries. Global Finance Journal, 7(1), 27-52.

[25]Lin, W.-L., R.F. Engle and T. Ito (1994). Do bulls and bears move across borders? International transmission of stock returns and volatility. Review of Financial Studies, 7 (3), 507-538.

[26]Miyakoshi, T. (2003). Spillovers of stock return volatility to Asian equity markets from Japan and the US. International Financial Markets, Institutions and Money, 13, 383-399.

[27]Ng, A. (2000). Volatility spillover effects from Japan and the US to the Pacific-Basin. Journal of International Money and Finance, 19, 207-233.

[28]Ross, S.A. (1989). Information and volatility: The no-arbitrage Martingale approach to timing and resolution irrelevancy. Journal of Finance, 44, 1-17.

[29]Susmel, R. and R.F. Engle (1994). Hourly volatility spillovers between international equity markets. Journal of International Money and Finance, 13(1), 3-25.

[30]Theodossiou, P. and U. Lee (1993). Mean and volatility spillovers across major national stock markets: Further empirical evidence. Journal of Financial Research, 16, 337-350. 
Table 1: Summary Descriptive Statistics

Panel A: Full Sample (31/12/84-8/10/04)

\begin{tabular}{lccccccc}
\hline \hline & Canada & France & Germany & Italy & Japan & UK & US \\
\hline \hline Mean & 0.00025 & 0.00035 & 0.00028 & 0.00029 & $9.59 \mathrm{E}-05$ & 0.00044 & 0.00034 \\
Median & 0.00049 & 0.00046 & 0.00032 & 0.00037 & 0.00000 & 0.00055 & 0.00025 \\
Maximum & 0.08874 & 0.08289 & 0.08769 & 0.07099 & 0.12883 & 0.07231 & 0.09095 \\
Minimum & -0.12111 & -0.08430 & -0.11494 & -0.10678 & -0.13823 & -0.14047 & -0.22899 \\
Std. Dev. & 0.00960 & 0.01355 & 0.01453 & 0.01304 & 0.01602 & 0.01150 & 0.01093 \\
Skewness & -1.17403 & -0.22157 & -0.29519 & -0.36396 & 0.11682 & -0.59935 & -2.07463 \\
Kurtosis & 17.7069 & 5.88741 & 7.16838 & 6.90276 & 7.63023 & 10.6913 & 47.1517 \\
\hline \hline
\end{tabular}

Panel B: First subsample (31/12/84-31/12/94)

\begin{tabular}{lccccccc}
\hline \hline & Canada & France & Germany & Italy & Japan & UK & US \\
\hline \hline Mean & 0.00016 & 0.00044 & 0.00031 & 0.00027 & 0.00048 & 0.00054 & 0.00033 \\
Median & 0.00037 & 0.00049 & 0.00000 & 0.00034 & 0.00053 & 0.00054 & 0.00029 \\
Maximum & 0.08874 & 0.08289 & 0.08769 & 0.07099 & 0.12883 & 0.07231 & 0.09095 \\
Minimum & -0.12111 & -0.08430 & -0.11494 & -0.10678 & -0.13823 & -0.14047 & -0.22899 \\
Std. Dev. & 0.00800 & 0.01317 & 0.01351 & 0.01397 & 0.01560 & 0.01179 & 0.01045 \\
Skewness & -2.07996 & -0.36377 & -0.50435 & -0.39156 & -0.01657 & -1.01165 & -4.80774 \\
Kurtosis & 43.4971 & 7.11751 & 10.3723 & 7.59009 & 10.1313 & 15.5090 & 108.379 \\
\hline \hline
\end{tabular}

Panel C: Second subsample (1/1/95-8/10/04)

\begin{tabular}{lccccccc}
\hline \hline & Canada & France & Germany & Italy & Japan & UK & US \\
\hline \hline Mean & 0.00034 & 0.00028 & 0.00027 & 0.00029 & -0.00025 & 0.00035 & 0.00035 \\
Median & 0.00064 & 0.00041 & 0.00053 & 0.00045 & -0.00043 & 0.00056 & 0.00017 \\
Maximum & 0.04690 & 0.06198 & 0.06837 & 0.05592 & 0.12354 & 0.05797 & 0.05574 \\
Minimum & -0.09033 & -0.07362 & -0.08559 & -0.07543 & -0.06592 & -0.05886 & -0.07114 \\
Std. Dev. & 0.01088 & 0.01389 & 0.01542 & 0.01213 & 0.01639 & 0.01124 & 0.01136 \\
Skewness & -0.80306 & -0.10832 & -0.16263 & -0.31626 & 0.22749 & -0.16387 & -0.10826 \\
Kurtosis & 8.96719 & 4.94645 & 5.24439 & 5.42687 & 5.72985 & 5.29419 & 6.25458 \\
\hline \hline
\end{tabular}


Table 2: Unrestricted Estimated GARCH(1,1)-BEKK Models

\begin{tabular}{|c|c|c|c|c|c|c|c|c|c|c|c|c|c|c|c|c|c|}
\hline \multicolumn{9}{|c|}{ Panel A: $1^{\text {st }}$ subsample (31/12/84-31/12/94) } & \multicolumn{9}{|c|}{ Panel B: $2^{\text {nd }}$ subsample $(1 / 1 / 95-8 / 10 / 04)$} \\
\hline & $\begin{array}{l}\mathrm{c}_{11} \\
\mathrm{c}_{21}\end{array}$ & $\mathrm{c}_{22}$ & $\begin{array}{l}\alpha_{11} \\
\alpha_{21}\end{array}$ & $\begin{array}{l}\alpha_{12} \\
\alpha_{22}\end{array}$ & $\begin{array}{l}b_{11} \\
b_{21}\end{array}$ & $\begin{array}{l}b_{12} \\
b_{22}\end{array}$ & $\begin{array}{l}\text { Eigen- } \\
\text { values }\end{array}$ & $\begin{array}{l}\text { d.f. } \\
\text { (s.e.) }\end{array}$ & & $\begin{array}{l}\mathrm{c}_{11} \\
\mathrm{c}_{21}\end{array}$ & $\mathrm{c}_{22}$ & $\begin{array}{l}\alpha_{11} \\
\alpha_{21}\end{array}$ & $\begin{array}{l}\alpha_{12} \\
\alpha_{22}\end{array}$ & $\begin{array}{l}b_{11} \\
b_{21}\end{array}$ & $\begin{array}{l}b_{12} \\
b_{22}\end{array}$ & $\begin{array}{l}\text { Eigen- } \\
\text { values }\end{array}$ & $\begin{array}{l}\text { d.f. } \\
\text { (s.e.) }\end{array}$ \\
\hline$\overline{\text { Canada }}$ & $\begin{array}{l}0.0013^{*} \\
(0.0001) \\
0.0004^{*} \\
(0.0001)\end{array}$ & $\begin{array}{l}0.0006^{*} \\
(0.0002)\end{array}$ & $\begin{array}{l}0.2596^{*} \\
(0.0291) \\
0.0656^{*} \\
(0.0331)\end{array}$ & $\begin{array}{c}-0.0173 \\
(0.0183) \\
0.1355^{*} \\
(0.0193)\end{array}$ & $\begin{array}{l}0.9387^{*} \\
(0.0116) \\
-0.029 * \\
(0.0128)\end{array}$ & $\begin{array}{l}0.0149 * \\
(0.0060) \\
0.9938^{*} \\
(0.0062)\end{array}$ & $\begin{array}{l}0.9885 \\
0.9710 \\
0.9692 \\
0.9625 \\
\end{array}$ & $\begin{array}{c}4.8333^{*} \\
(0.3160) \\
\text { LL } \\
17066.3\end{array}$ & Canada & $\begin{array}{c}0.0007^{*} \\
(0.0001) \\
0.0005^{*} \\
(0.0002)\end{array}$ & $\begin{array}{l}0.0006^{*} \\
(0.0001)\end{array}$ & $\begin{array}{c}0.2125^{*} \\
(0.0183) \\
0.0344 \\
(0.0208)\end{array}$ & $\begin{array}{c}0.0314 \\
(0.0185) \\
0.2301^{*} \\
(0.0213)\end{array}$ & $\begin{array}{c}0.9747^{*} \\
(0.0043) \\
-0.0074 \\
(0.0054)\end{array}$ & $\begin{array}{c}-0.0074 \\
(0.0050) \\
0.9705^{*} \\
(0.0055)\end{array}$ & $\begin{array}{l}0.9963 \\
0.9961 \\
0.9940 \\
0.9939\end{array}$ & $\begin{array}{c}7.3849^{*} \\
(0.5860) \\
\text { LL } \\
17029.1\end{array}$ \\
\hline France & $\begin{array}{c}0.0036^{*} \\
(0.0004) \\
0.0004 \\
(0.0002) \\
\end{array}$ & $\begin{array}{l}0.0007^{*} \\
(0.0001)\end{array}$ & $\begin{array}{c}0.2614^{*} \\
(0.0280) \\
-0.0110 \\
(0.0146) \\
\end{array}$ & $\begin{array}{l}0.0545^{*} \\
(0.0221) \\
0.1533^{*} \\
(0.0130)\end{array}$ & $\begin{array}{c}0.9213^{*} \\
(0.0160) \\
-0.0019 \\
(0.0073) \\
\end{array}$ & $\begin{array}{l}-0.0012 \\
(0.0078) \\
0.9830^{*} \\
(0.0026)\end{array}$ & $\begin{array}{l}0.9890 \\
0.9458 \\
0.9425 \\
0.9214 \\
\end{array}$ & $\begin{array}{c}5.6514^{*} \\
(0.4033) \\
\text { LL } \\
15138.7\end{array}$ & France & $\begin{array}{c}0.0013^{*} \\
(0.0002) \\
-0.0003 \\
(0.0002)\end{array}$ & $\begin{array}{l}0.0008^{*} \\
(0.0001)\end{array}$ & $\begin{array}{c}0.2167 * \\
(0.0189) \\
0.0106 \\
(0.0164)\end{array}$ & $\begin{array}{c}-0.0271 \\
(0.0235) \\
0.2315^{*} \\
(0.0186)\end{array}$ & $\begin{array}{c}0.9692 * \\
(0.0057) \\
0.0018 \\
(0.0051)\end{array}$ & $\begin{array}{c}0.0110 \\
(0.0071) \\
0.9682^{*} \\
(0.0053)\end{array}$ & $\begin{array}{l}0.9977 \\
0.9886 \\
0.9883 \\
0.9798 \\
\end{array}$ & $\begin{array}{c}8.4343^{*} \\
(0.8219) \\
\text { LL } \\
15977.8 \\
\end{array}$ \\
\hline Germany & $\begin{array}{l}0.0028^{*} \\
(0.0003) \\
-0.0001 \\
(0.0001) \\
\end{array}$ & $\begin{array}{l}0.0008^{*} \\
(0.0001) \\
\end{array}$ & $\begin{array}{c}0.2738^{*} \\
(0.0257) \\
-0.0064 \\
(0.0137) \\
\end{array}$ & $\begin{array}{c}0.0423^{*} \\
(0.0207) \\
0.1415^{*} \\
(0.0123) \\
\end{array}$ & $\begin{array}{c}0.9339^{*} \\
(0.0109) \\
0.0041 \\
(0.0055) \\
\end{array}$ & $\begin{array}{c}0.0044 \\
(0.0067) \\
0.9828^{*} \\
(0.0027) \\
\end{array}$ & $\begin{array}{l}0.9881 \\
0.9593 \\
0.9566 \\
0.9423 \\
\end{array}$ & $\begin{array}{c}5.2204 * \\
(0.3353) \\
\text { LL } \\
15197.8 \\
\end{array}$ & Germany & $\begin{array}{c}0.0007^{*} \\
(0.0002) \\
-0.0003 \\
(0.0002)\end{array}$ & $\begin{array}{l}0.0009^{*} \\
(0.0001)\end{array}$ & $\begin{array}{c}0.2205^{*} \\
(0.0165) \\
0.0017 \\
(0.0122)\end{array}$ & $\begin{array}{c}0.0384 \\
(0.0227) \\
0.2415^{*} \\
(0.0162)\end{array}$ & $\begin{array}{c}0.9733^{*} \\
(0.0043) \\
0.0021 \\
(0.0034)\end{array}$ & $\begin{array}{l}-0.0055 \\
(0.0069) \\
0.9656^{*} \\
(0.0047)\end{array}$ & $\begin{array}{l}0.9997 \\
0.9932 \\
0.9931 \\
0.9869\end{array}$ & $\begin{array}{c}8.4185^{*} \\
(0.8173) \\
\text { LL } \\
15921.2\end{array}$ \\
\hline Italy & $\begin{array}{c}0.0021^{*} \\
(0.0003) \\
0.0002 \\
(0.0001) \\
\end{array}$ & $\begin{array}{l}0.0007^{*} \\
(0.0001) \\
\end{array}$ & $\begin{array}{c}0.2436^{*} \\
(0.0223) \\
0.0082 \\
(0.0107) \\
\end{array}$ & $\begin{array}{c}0.0132 \\
(0.0163) \\
0.1477^{*} \\
(0.0121) \\
\end{array}$ & $\begin{array}{c}0.9584 * \\
(0.0076) \\
-0.0027 \\
(0.0036) \\
\end{array}$ & $\begin{array}{l}-0.0044 \\
(0.0046) \\
0.9836^{*} \\
(0.0022) \\
\end{array}$ & $\begin{array}{l}0.9896 \\
0.9786 \\
0.9784 \\
0.9780 \\
\end{array}$ & $\begin{array}{c}5.6541^{*} \\
(0.4018) \\
\text { LL } \\
14978.5 \\
\end{array}$ & Italy & $\begin{array}{c}0.0017^{*} \\
(0.0002) \\
0.0001 \\
(0.0002) \\
\end{array}$ & $\begin{array}{l}0.0007^{*} \\
(0.0001)\end{array}$ & $\begin{array}{c}0.2409^{*} \\
(0.0205) \\
0.0236 \\
(0.0180) \\
\end{array}$ & $\begin{array}{c}0.0068 \\
(0.0180) \\
0.2293^{*} \\
(0.0165) \\
\end{array}$ & $\begin{array}{c}0.9572 * \\
(0.0074) \\
-0.0067 \\
(0.0064) \\
\end{array}$ & $\begin{array}{c}0.0027 \\
(0.0053) \\
0.9718^{*} \\
(0.0042) \\
\end{array}$ & $\begin{array}{l}0.9964 \\
0.9863 \\
0.9855 \\
0.9745 \\
\end{array}$ & $\begin{array}{c}8.6927^{*} \\
(0.8834) \\
\text { LL } \\
16219.0 \\
\end{array}$ \\
\hline Japan & $\begin{array}{c}0.0025^{*} \\
(0.0002) \\
0.0002 \\
(0.0002) \\
\end{array}$ & $\begin{array}{l}0.0007 * \\
(0.0001) \\
\end{array}$ & $\begin{array}{c}0.3437^{*} \\
(0.0235) \\
0.0243^{*} \\
(0.0100) \\
\end{array}$ & $\begin{array}{l}0.0593^{*} \\
(0.0279) \\
0.1537^{*} \\
(0.0122) \\
\end{array}$ & $\begin{array}{c}0.9281^{*} \\
(0.0089) \\
-0.008^{*} \\
(0.0038) \\
\end{array}$ & $\begin{array}{l}-0.0104 \\
(0.0074) \\
0.9827^{*} \\
(0.0024) \\
\end{array}$ & $\begin{array}{l}0.9898 \\
0.9808 \\
0.9648 \\
0.9634 \\
\end{array}$ & $\begin{array}{c}5.2258^{*} \\
(0.3588) \\
\text { LL } \\
14890.7 \\
\end{array}$ & Japan & $\begin{array}{c}0.0020^{*} \\
(0.0003) \\
-0.0002 \\
(0.0002) \\
\end{array}$ & $\begin{array}{c}0.0007^{*} \\
(0.0001) \\
\end{array}$ & $\begin{array}{l}0.2072 * \\
(0.0170) \\
-0.026^{*} \\
(0.0132) \\
\end{array}$ & $\begin{array}{c}0.0069 \\
(0.0249) \\
0.2308^{*} \\
(0.0153) \\
\end{array}$ & $\begin{array}{c}0.9696^{*} \\
(0.0050) \\
0.0049 \\
(0.0039) \\
\end{array}$ & $\begin{array}{c}0.0041 \\
(0.0063) \\
0.9709^{*} \\
(0.0038) \\
\end{array}$ & $\begin{array}{l}0.9946 \\
0.9902 \\
0.9893 \\
0.9837 \\
\end{array}$ & $\begin{array}{c}8.3958^{*} \\
(0.8265) \\
\text { LL } \\
15242.6 \\
\end{array}$ \\
\hline$\overline{U K}$ & $\begin{array}{c}0.0031^{*} \\
(0.0004) \\
0.0004 \\
(0.0002)\end{array}$ & $\begin{array}{l}0.0008^{*} \\
(0.0001)\end{array}$ & $\begin{array}{c}0.2693 * \\
(0.0304) \\
-0.0049 \\
(0.0188)\end{array}$ & $\begin{array}{c}0.0061 \\
(0.0250) \\
0.1656^{*} \\
(0.0135)\end{array}$ & $\begin{array}{c}0.9239^{*} \\
(0.0164) \\
-0.0020 \\
(0.0090)\end{array}$ & $\begin{array}{c}0.0057 \\
(0.0073) \\
0.9796^{*} \\
(0.0033)\end{array}$ & $\begin{array}{l}0.9864 \\
0.9497 \\
0.9485 \\
0.9281\end{array}$ & $\begin{array}{c}6.0113^{*} \\
(0.4041) \\
\text { LL } \\
15438.0\end{array}$ & $U K$ & $\begin{array}{c}0.0013^{*} \\
(0.0001) \\
-0.000^{*} \\
(0.0002)\end{array}$ & $\begin{array}{l}0.0008^{*} \\
(0.0002)\end{array}$ & $\begin{array}{l}0.2186^{*} \\
(0.0170) \\
0.0565^{*} \\
(0.0182)\end{array}$ & $\begin{array}{c}-0.095^{*} \\
(0.0191) \\
0.2343^{*} \\
(0.0209)\end{array}$ & $\begin{array}{c}0.9574 * \\
(0.0065) \\
0.0003 \\
(0.0075)\end{array}$ & $\begin{array}{l}0.0320^{*} \\
(0.0073) \\
0.9623^{*} \\
(0.0072)\end{array}$ & $\begin{array}{l}0.9976 \\
0.9776 \\
0.9649 \\
0.9506\end{array}$ & $\begin{array}{c}9.0356^{*} \\
(0.8716) \\
\text { LL } \\
16512.5\end{array}$ \\
\hline
\end{tabular}

Notes: Standard errors are reported in parentheses. An asterisk indicates significance at the $5 \%$ level. $d . f$. refers to degrees of freedom of the t-distribution. LL

refers to the value of the log-likelihood function. 
Table 3: Restricted Estimated GARCH(1,1)-BEKK Models

\begin{tabular}{|c|c|c|c|c|c|c|c|c|c|c|c|c|c|c|c|c|c|}
\hline \multicolumn{9}{|c|}{ Panel A: $1^{\text {st }}$ subsample (31/12/84-31/12/94) } & \multicolumn{9}{|c|}{ Panel B: $2^{\text {nd }}$ subsample(1/1/95-8/10/04) } \\
\hline & $\begin{array}{l}\mathrm{c}_{11} \\
\mathrm{c}_{21}\end{array}$ & $\mathrm{c}_{22}$ & $\begin{array}{l}\alpha_{11} \\
\alpha_{21}\end{array}$ & $\begin{array}{l}\alpha_{12} \\
\alpha_{22}\end{array}$ & $\begin{array}{l}b_{11} \\
b_{21}\end{array}$ & $\begin{array}{l}b_{12} \\
b_{22}\end{array}$ & $\begin{array}{l}\text { Eigen- } \\
\text { values }\end{array}$ & $\begin{array}{l}\text { d.f. } \\
\text { (s.e.) }\end{array}$ & & $\begin{array}{l}\mathrm{c}_{11} \\
\mathrm{c}_{21}\end{array}$ & $c_{22}$ & $\begin{array}{l}\alpha_{11} \\
\alpha_{21}\end{array}$ & $\begin{array}{l}\alpha_{12} \\
\alpha_{22}\end{array}$ & $\begin{array}{l}b_{11} \\
b_{21}\end{array}$ & $\begin{array}{l}b_{12} \\
b_{22}\end{array}$ & $\begin{array}{l}\text { Eigen- } \\
\text { values }\end{array}$ & $\begin{array}{l}\text { d.f. } \\
\text { (s.e.) }\end{array}$ \\
\hline Canada & $\begin{array}{l}0.0010^{*} \\
(0.0001)\end{array}$ & $\begin{array}{l}0.0007 * \\
(0.0001)\end{array}$ & $\begin{array}{l}0.2161 * \\
(0.0170)\end{array}$ & $\begin{array}{l}0.1580^{*} \\
(0.0125)\end{array}$ & $\begin{array}{l}0.9567^{*} \\
(0.0073)\end{array}$ & $\begin{array}{l}0.0099^{*} \\
(0.0026) \\
0.9835^{*} \\
(0.0022)\end{array}$ & $\begin{array}{c}0.9923 \\
0.975 \\
0.975 \\
0.9619\end{array}$ & $\begin{array}{c}5.0970 * \\
(0.3232) \\
\text { LL } \\
17065.9\end{array}$ & Canada & $\begin{array}{c}0.0007^{*} \\
(0.0001) \\
0.0006^{*} \\
(0.0002)\end{array}$ & $\begin{array}{l}0.0007 * \\
(0.0001)\end{array}$ & $\begin{array}{l}0.1896^{*} \\
(0.0132)\end{array}$ & $\begin{array}{c}0.0495^{*} \\
(0.0164) \\
0.2555^{*} \\
(0.0169)\end{array}$ & $\begin{array}{l}0.9796^{*} \\
(0.0028)\end{array}$ & $\begin{array}{c}-0.0116^{*} \\
(0.0042) \\
0.9652 * \\
(0.0044)\end{array}$ & $\begin{array}{l}0.9968 \\
0.9956 \\
0.9939 \\
0.9939\end{array}$ & $\begin{array}{c}7.3827^{*} \\
(0.5843) \\
\text { LL } \\
17026.8\end{array}$ \\
\hline France & $\begin{array}{c}0.0036^{*} \\
(0.0004) \\
0.0002^{*} \\
(0.0001)\end{array}$ & $\begin{array}{l}0.0008^{*} \\
(0.0001)\end{array}$ & $\begin{array}{l}0.2692 * \\
(0.0263)\end{array}$ & $\begin{array}{c}0.0424 * \\
(0.0197) \\
0.1465 * \\
(0.0122) \\
\end{array}$ & $\begin{array}{l}0.9218^{*} \\
(0.0143)\end{array}$ & $\begin{array}{l}0.9834^{*} \\
(0.0023)\end{array}$ & $\begin{array}{l}0.9886 \\
0.9459 \\
0.9459 \\
0.9221 \\
\end{array}$ & $\begin{array}{c}5.6243 * \\
(0.3983) \\
\text { LL } \\
15137.2 \\
\end{array}$ & France & $\begin{array}{l}0.0015^{*} \\
(0.0002)\end{array}$ & $\begin{array}{c}0.0008^{*} \\
(0.0001)\end{array}$ & $\begin{array}{l}0.2108^{*} \\
(0.0162)\end{array}$ & $\begin{array}{l}0.2375^{*} \\
(0.0148)\end{array}$ & $\begin{array}{l}0.9696^{*} \\
(0.0047)\end{array}$ & $\begin{array}{c}0.0064 * \\
(0.0020) \\
0.9694 * \\
(0.0036) \\
\end{array}$ & $\begin{array}{l}0.9962 \\
0.9900 \\
0.9900 \\
0.9846\end{array}$ & $\begin{array}{c}8.4791^{*} \\
(0.8214) \\
\text { LL } \\
15975.4\end{array}$ \\
\hline Germany & $\begin{array}{l}0.0028^{*} \\
(0.0003)\end{array}$ & $\begin{array}{l}0.0009 * \\
(0.0001)\end{array}$ & $\begin{array}{l}0.2667^{*} \\
(0.0221)\end{array}$ & $\begin{array}{c}0.0545^{*} \\
(0.0152) \\
0.1445^{*} \\
(0.0109)\end{array}$ & $\begin{array}{l}0.9373^{*} \\
(0.0089)\end{array}$ & $\begin{array}{l}0.9835^{*} \\
(0.0022)\end{array}$ & $\begin{array}{l}0.9881 \\
0.9603 \\
0.9603 \\
0.9496\end{array}$ & $\begin{array}{c}5.2190^{*} \\
(0.3334) \\
\text { LL } \\
15196.3\end{array}$ & Germany & $\begin{array}{l}0.0009^{*} \\
(0.0002)\end{array}$ & $\begin{array}{l}0.0009 * \\
(0.0001)\end{array}$ & $\begin{array}{l}0.2233^{*} \\
(0.0145)\end{array}$ & $\begin{array}{c}0.0187^{*} \\
(0.0075) \\
0.2358^{*} \\
(0.0146)\end{array}$ & $\begin{array}{l}0.9726^{*} \\
(0.0033)\end{array}$ & $\begin{array}{l}0.9700^{*} \\
(0.0036)\end{array}$ & $\begin{array}{l}0.9964 \\
0.9959 \\
0.9959 \\
0.9957\end{array}$ & $\begin{array}{c}8.4130^{*} \\
(0.8164) \\
\text { LL } \\
15919.6\end{array}$ \\
\hline Italy & $\begin{array}{l}0.0021^{*} \\
(0.0003)\end{array}$ & $\begin{array}{l}0.0008^{*} \\
(0.0001) \\
\end{array}$ & $\begin{array}{l}0.2426^{*} \\
(0.0216)\end{array}$ & $\begin{array}{c}0.1435^{*} \\
(0.0121) \\
\end{array}$ & $\begin{array}{l}0.9596 * \\
(0.0072)\end{array}$ & $\begin{array}{l}0.9845^{*} \\
(0.0022) \\
\end{array}$ & $\begin{array}{l}0.9898 \\
0.9796 \\
0.9795 \\
0.9795 \\
\end{array}$ & $\begin{array}{c}5.6196^{*} \\
(0.3938) \\
\text { LL } \\
14977.0 \\
\end{array}$ & Italy & $\begin{array}{l}0.0017 * \\
(0.0002)\end{array}$ & $\begin{array}{c}0.0008^{*} \\
(0.0001) \\
\end{array}$ & $\begin{array}{l}0.2335^{*} \\
(0.0193)\end{array}$ & $\begin{array}{l}0.2336^{*} \\
(0.0154) \\
\end{array}$ & $\begin{array}{l}0.9597^{*} \\
(0.0068)\end{array}$ & $\begin{array}{c}0.0044 * \\
(0.0017) \\
0.9705^{*} \\
(0.0037) \\
\end{array}$ & $\begin{array}{l}0.9964 \\
0.9859 \\
0.9859 \\
0.9755 \\
\end{array}$ & $\begin{array}{c}8.6295^{*} \\
(0.8451) \\
\text { LL } \\
16217.8 \\
\end{array}$ \\
\hline Japan & $\begin{array}{l}0.0025^{*} \\
(0.0003)\end{array}$ & $\begin{array}{l}0.0008^{*} \\
(0.0001) \\
\end{array}$ & $\begin{array}{l}0.3386^{*} \\
(0.0231)\end{array}$ & $\begin{array}{l}0.1569 * \\
(0.0128) \\
\end{array}$ & $\begin{array}{l}0.9317 * \\
(0.0085)\end{array}$ & $\begin{array}{l}0.9821^{*} \\
(0.0025) \\
\end{array}$ & $\begin{array}{l}0.9891 \\
0.9827 \\
0.9681 \\
0.9681 \\
\end{array}$ & $\begin{array}{c}5.1422 * \\
(0.3418) \\
\text { LL } \\
14885.1 \\
\end{array}$ & Japan & $\begin{array}{l}0.0021^{*} \\
(0.0003)\end{array}$ & $\begin{array}{c}0.0008 * \\
(0.0001) \\
\end{array}$ & $\begin{array}{c}0.2112^{*} \\
(0.0171) \\
-0.0115^{*} \\
(0.0058) \\
\end{array}$ & $\begin{array}{c}0.2323 * \\
(0.0151) \\
\end{array}$ & $\begin{array}{l}0.9682 * \\
(0.0052)\end{array}$ & $\begin{array}{c}0.0060^{*} \\
(0.0025) \\
0.9712 * \\
(0.0036) \\
\end{array}$ & $\begin{array}{l}0.9936 \\
0.9893 \\
0.9874 \\
0.9874 \\
\end{array}$ & $\begin{array}{c}8.4674 * \\
(0.8384) \\
\text { LL } \\
15240.8 \\
\end{array}$ \\
\hline$U K$ & $\begin{array}{c}0.0028 * \\
(0.0004) \\
0.0003 * \\
(0.0001)\end{array}$ & $\begin{array}{l}0.0009 * \\
(0.0001)\end{array}$ & $\begin{array}{l}0.2601^{*} \\
(0.0270)\end{array}$ & $\begin{array}{l}0.1631 * \\
(0.0130)\end{array}$ & $\begin{array}{l}0.9355^{*} \\
(0.0130)\end{array}$ & $\begin{array}{l}0.9791 * \\
(0.0028)\end{array}$ & $\begin{array}{l}0.9851 \\
0.9583 \\
0.9583 \\
0.9428\end{array}$ & $\begin{array}{c}6.0111^{*} \\
(0.3949) \\
\text { LL } \\
15437.0\end{array}$ & $U K$ & $\begin{array}{c}0.0014^{*} \\
(0.0002) \\
-0.0006^{*} \\
(0.0002)\end{array}$ & $\begin{array}{l}0.0008^{*} \\
(0.0002)\end{array}$ & $\begin{array}{c}0.2192 * \\
(0.0168) \\
0.0561 * \\
(0.0145)\end{array}$ & $\begin{array}{c}-0.0943^{*} \\
(0.0190) \\
0.2347^{*} \\
(0.0160)\end{array}$ & $\begin{array}{l}0.9575^{*} \\
(0.0063)\end{array}$ & $\begin{array}{c}0.0317 * \\
(0.0070) \\
0.9626^{*} \\
(0.0043)\end{array}$ & $\begin{array}{l}0.9976 \\
0.9781 \\
0.9658 \\
0.9513\end{array}$ & $\begin{array}{c}9.0840 * \\
(0.8752) \\
\text { LL } \\
16511.2\end{array}$ \\
\hline
\end{tabular}


Table 4: Likelihood Ratio Tests

\begin{tabular}{ccccccc}
\hline \hline & Canada & France & Germany & Italy & Japan & UK \\
\hline \hline$I^{\text {st }}$ subsample & & & & & \\
\hline $\begin{array}{c}\text { LR-stat. } \\
\text { d.f. }\end{array}$ & 0.8529 & 3.1034 & 3.0371 & 2.8405 & 11.2143 & 2.0793 \\
p-value & 6 & 6 & 7 & 8 & 8 & 7 \\
\hline \hline $2^{\text {nd }}$ subsample & 0.9906 & 0.7958 & 0.8815 & 0.9440 & 0.1898 & 0.9553 \\
\hline $\begin{array}{c}\text { LR-stat. } \\
\text { d.f. }\end{array}$ & 4.4864 & 4.8151 & 3.1584 & 2.4012 & 3.6086 & 2.6975 \\
p-value & 5 & 5 & 5 & 6 & 6 & 2 \\
\hline \hline Notes: The null hypothesis tested is: Restricted Model preferred to Unrestricted Model.
\end{tabular}

Table 5: Historical Shocks

\begin{tabular}{ccccccc}
\hline \hline & Canada & France & Germany & Italy & Japan & UK \\
\hline \hline Crash 1987 & & & & & & \\
\hline$Z_{10}$ & -9.74 & -3.99 & -2.46 & -3.63 & -7.28 & -8.63 \\
$Z_{20}$ & -14.04 & -16.85 & -16.97 & -17.39 & -17.32 & -15.74 \\
\hline \hline Asian Crisis & & & & & & \\
\hline$Z_{10}$ & -8.83 & 0.68 & -0.41 & -0.82 & -1.37 & 0.96 \\
$Z_{20}$ & -4.24 & -7.47 & -7.07 & -6.82 & -6.85 & -7.05 \\
\hline \hline Twin Towers & & & & & & \\
$Z_{10}$ & 1.16 & 0.68 & -0.41 & -2.37 & -1.97 & 2.79 \\
$Z_{20}$ & -5.27 & -7.47 & -7.07 & -4.65 & -4.88 & -5.76 \\
\hline \hline
\end{tabular}

Table 6: Initial State $\mathbf{H}_{0}$

\begin{tabular}{ccccccc}
\hline \hline & Canada & France & Germany & Italy & Japan & UK \\
\hline \hline$h_{11,0}$ & 0.7390 & 1.0380 & 1.0517 & 0.5925 & 1.4174 & 0.5321 \\
$h_{12,0}$ & 0.3397 & 0.4019 & 0.4491 & 0.1299 & 0.2504 & 0.1942 \\
$h_{22,0}$ & 0.5724 & 0.5587 & 0.5553 & 0.5486 & 0.5272 & 0.5993 \\
\hline \hline
\end{tabular}

Notes: Figures are expressed in $10^{-4}$. 
Table 7: Maximum Volatility Impulse Responses

\begin{tabular}{|c|c|c|c|c|c|c|}
\hline \multicolumn{7}{|c|}{ Panel A: Crash 1987} \\
\hline & Canada & France & Germany & Italy & Japan & $U K$ \\
\hline \multicolumn{7}{|l|}{$1^{\text {st }}$ subsample } \\
\hline$v_{1,1} / h_{11,0}$ & $\begin{array}{c}7.84 \\
(7.84)\end{array}$ & $\begin{array}{c}6.86 \\
(6.86)\end{array}$ & $\begin{array}{c}6.03 \\
(6.03)\end{array}$ & $\begin{array}{c}1.76 \\
(1.76)\end{array}$ & $\begin{array}{c}9.50 \\
(9.50)\end{array}$ & $\begin{array}{c}8.60 \\
(8.60)\end{array}$ \\
\hline$v_{2,1} / h_{12,0}$ & $\begin{array}{c}13.78 \\
(13.78)\end{array}$ & $\begin{array}{c}12.56 \\
(12.56)\end{array}$ & $\begin{array}{c}10.12 \\
(10.12)\end{array}$ & $\begin{array}{l}15.01 \\
(15.01)\end{array}$ & $\begin{array}{c}30.78 \\
(30.78)\end{array}$ & $\begin{array}{c}23.65 \\
(23.65)\end{array}$ \\
\hline$v_{3,1} / h_{22,0}$ & $\begin{array}{c}6.57 \\
(6.57) \\
\end{array}$ & $\begin{array}{c}6.36 \\
(6.36) \\
\end{array}$ & $\begin{array}{c}5.82 \\
(5.82) \\
\end{array}$ & $\begin{array}{c}6.43 \\
(6.43) \\
\end{array}$ & $\begin{array}{c}8.27 \\
(8.27) \\
\end{array}$ & $\begin{array}{c}7.63 \\
(7.63) \\
\end{array}$ \\
\hline \multicolumn{7}{|c|}{$2^{\text {nd }}$ subsample } \\
\hline$v_{1,1} / h_{11,0}$ & $\begin{array}{c}10.01 \\
(10.01)\end{array}$ & $\begin{array}{c}3.68 \\
(2.65)\end{array}$ & $\begin{array}{c}8.99 \\
(2.98)\end{array}$ & $\begin{array}{c}1.69 \\
(1.63)\end{array}$ & $\begin{array}{c}3.70 \\
(3.70)\end{array}$ & $\begin{array}{c}6.89 \\
(0.57)\end{array}$ \\
\hline$v_{2,1} / h_{12,0}$ & $\begin{array}{l}25.15 \\
(25.15)\end{array}$ & $\begin{array}{c}12.94 \\
(12.69)\end{array}$ & $\begin{array}{c}13.63 \\
(11.63)\end{array}$ & $\begin{array}{l}23.51 \\
(23.51)\end{array}$ & $\begin{array}{l}27.29 \\
(27.29)\end{array}$ & $\begin{array}{c}16.55 \\
(10.42)\end{array}$ \\
\hline$v_{3,1} / h_{22,0}$ & $\begin{array}{c}17.18 \\
(17.18) \\
\end{array}$ & $\begin{array}{c}16.72 \\
(16.72) \\
\end{array}$ & $\begin{array}{c}15.50 \\
(15.50) \\
\end{array}$ & $\begin{array}{c}17.03 \\
(17.03) \\
\end{array}$ & $\begin{array}{c}16.69 \\
(16.69) \\
\end{array}$ & $\begin{array}{c}20.92 \\
(20.92) \\
\end{array}$ \\
\hline \multicolumn{7}{|c|}{ Panel B: Asian Crisis } \\
\hline & Canada & France & Germany & Italy & Japan & $U K$ \\
\hline \multicolumn{7}{|l|}{$1^{\text {st }}$ subsample } \\
\hline$v_{1,1} / h_{11,0}$ & $\begin{array}{c}4.27 \\
(4.27)\end{array}$ & $\begin{array}{c}0.17 \\
(0.17)\end{array}$ & $\begin{array}{c}0.66 \\
(0.66)\end{array}$ & $\begin{array}{c}0.09 \\
(0.09)\end{array}$ & $\begin{array}{c}0.40 \\
(0.40)\end{array}$ & $\begin{array}{c}-0.06 \\
(-0.06)\end{array}$ \\
\hline$v_{2,1} / h_{12,0}$ & $\begin{array}{c}4.12 \\
(4.12)\end{array}$ & $\begin{array}{c}0.91 \\
(0.91)\end{array}$ & $\begin{array}{c}1.38 \\
(1.38)\end{array}$ & $\begin{array}{c}1.62 \\
(1.62)\end{array}$ & $\begin{array}{c}2.66 \\
(2.66)\end{array}$ & $\begin{array}{c}0.23 \\
(0.23)\end{array}$ \\
\hline$v_{3,1} / h_{22,0}$ & $\begin{array}{c}1.06 \\
(1.06) \\
\end{array}$ & $\begin{array}{r}0.99 \\
(0.99) \\
\end{array}$ & $\begin{array}{r}0.93 \\
(0.93) \\
\end{array}$ & $\begin{array}{r}0.95 \\
(0.95) \\
\end{array}$ & $\begin{array}{c}1.18 \\
(1.18) \\
\end{array}$ & $\begin{array}{c}1.20 \\
(1.20) \\
\end{array}$ \\
\hline \multicolumn{7}{|c|}{$2^{\text {nd }}$ subsample } \\
\hline$v_{1,1} / h_{11,0}$ & $\begin{array}{c}4.41 \\
(4.41)\end{array}$ & $\begin{array}{c}0.40 \\
(0.01)\end{array}$ & $\begin{array}{c}1.31 \\
(0.29)\end{array}$ & $\begin{array}{c}0.19 \\
(0.08)\end{array}$ & $\begin{array}{c}0.24 \\
(0.16)\end{array}$ & $\begin{array}{c}0.40 \\
(0.33)\end{array}$ \\
\hline$v_{2,1} / h_{12,0}$ & $\begin{array}{c}6.75 \\
(6.75)\end{array}$ & $\begin{array}{c}1.41 \\
(0.65)\end{array}$ & $\begin{array}{r}1.99 \\
(1.54)\end{array}$ & $\begin{array}{c}2.72 \\
(2.54)\end{array}$ & $\begin{array}{c}2.43 \\
(2.41)\end{array}$ & $\begin{array}{c}-2.86 \\
(-2.86)\end{array}$ \\
\hline$v_{3,1} / h_{22,0}$ & $\begin{array}{r}2.78 \\
(2.78) \\
\end{array}$ & $\begin{array}{r}2.61 \\
(2.61) \\
\end{array}$ & $\begin{array}{r}2.48 \\
(2.48) \\
\end{array}$ & $\begin{array}{r}2.52 \\
(2.52) \\
\end{array}$ & $\begin{array}{r}2.46 \\
(2.46) \\
\end{array}$ & $\begin{array}{r}2.53 \\
(2.53) \\
\end{array}$ \\
\hline \multicolumn{7}{|c|}{ Panel C: Twin Towers } \\
\hline & Canada & France & Germany & Italy & Japan & $U K$ \\
\hline \multicolumn{7}{|l|}{$I^{\text {st }}$ subsample } \\
\hline$v_{1,1} / h_{11,0}$ & $\begin{array}{c}-0.04 \\
(-0.04)\end{array}$ & $\begin{array}{c}-0.08 \\
(-0.08)\end{array}$ & $\begin{array}{c}-0.06 \\
(-0.06)\end{array}$ & $\begin{array}{c}0.43 \\
(0.43)\end{array}$ & $\begin{array}{c}0.60 \\
(0.60)\end{array}$ & $\begin{array}{c}0.13 \\
(0.13)\end{array}$ \\
\hline$v_{2,1} / h_{12,0}$ & $\begin{array}{c}0.21 \\
(0.03)\end{array}$ & $\begin{array}{c}-0.08 \\
(-0.08)\end{array}$ & $\begin{array}{c}0.12 \\
(0.12)\end{array}$ & $\begin{array}{c}2.11 \\
(2.11)\end{array}$ & $\begin{array}{c}2.31 \\
(2.31)\end{array}$ & $\begin{array}{c}-1.14 \\
(-1.14)\end{array}$ \\
\hline$v_{3,1} / h_{22,0}$ & $\begin{array}{r}0.53 \\
(0.53) \\
\end{array}$ & $\begin{array}{c}0.39 \\
(0.39) \\
\end{array}$ & $\begin{array}{r}0.40 \\
(0.40) \\
\end{array}$ & $\begin{array}{r}0.47 \\
(0.47) \\
\end{array}$ & $\begin{array}{r}0.63 \\
(0.63) \\
\end{array}$ & $\begin{array}{c}0.69 \\
(0.69) \\
\end{array}$ \\
\hline \multicolumn{7}{|c|}{$2^{\text {nd }}$ subsample } \\
\hline$v_{1,1} / h_{11,0}$ & $\begin{array}{c}0.15 \\
(0.01)\end{array}$ & $\begin{array}{c}0.13 \\
(-0.03)\end{array}$ & $\begin{array}{c}0.37 \\
(-0.05)\end{array}$ & $\begin{array}{c}0.40 \\
(0.40)\end{array}$ & $\begin{array}{c}0.23 \\
(0.23)\end{array}$ & $\begin{array}{c}0.76 \\
(0.76)\end{array}$ \\
\hline$v_{2,1} / h_{12,0}$ & $\begin{array}{c}0.50 \\
(0.50)\end{array}$ & $\begin{array}{c}0.44 \\
(-0.30)\end{array}$ & $\begin{array}{c}0.57 \\
(0.01)\end{array}$ & $\begin{array}{c}3.31 \\
(3.31)\end{array}$ & $\begin{array}{c}2.06 \\
(2.06)\end{array}$ & $\begin{array}{c}-2.95 \\
(-2.95)\end{array}$ \\
\hline$v_{3,1} / h_{22,0}$ & $\begin{array}{c}1.38 \\
(1.38) \\
\end{array}$ & $\begin{array}{c}1.04 \\
(1.04) \\
\end{array}$ & $\begin{array}{c}1.07 \\
(1.07) \\
\end{array}$ & $\begin{array}{c}1.25 \\
(1.25) \\
\end{array}$ & $\begin{array}{c}1.27 \\
(1.27) \\
\end{array}$ & $\begin{array}{c}1.21 \\
(1.21) \\
\end{array}$ \\
\hline
\end{tabular}

Notes: 1-step ahead volatility impulse responses in parentheses. Figures are scaled by the initial state. 
Table 8: Half-Life of Volatility Impulse Responses

\begin{tabular}{|c|c|c|c|c|c|c|}
\hline & Canada & France & Germany & Italy & Japan & $U K$ \\
\hline \multicolumn{7}{|c|}{$1^{s t}$ subsample } \\
\hline$h_{11}$ & 34 & 13 & 25 & 35 & 41 & 13 \\
\hline$h_{12}$ & 46 & 15 & 22 & 35 & 23 & 18 \\
\hline$h_{22}$ & 91 & 62 & 60 & 70 & 65 & 48 \\
\hline \multicolumn{7}{|c|}{$2^{\text {nd }}$ subsample } \\
\hline$h_{11}$ & 130 & 305 & 548 & 274 & 155 & 336 \\
\hline$h_{12}$ & 164 & 292 & 443 & 249 & 121 & 339 \\
\hline$h_{22}$ & 219 & 184 & 194 & 195 & 98 & 98 \\
\hline \multicolumn{7}{|c|}{ Panel B: Asian Crisis } \\
\hline & Canada & France & Germany & Italy & Japan & $U K$ \\
\hline \multicolumn{7}{|c|}{$1^{\text {st }}$ subsample } \\
\hline$h_{11}$ & 25 & 24 & 30 & 35 & 41 & 13 \\
\hline$h_{12}$ & 36 & 18 & 23 & 35 & 23 & 18 \\
\hline$h_{22}$ & 91 & 62 & 60 & 70 & 65 & 48 \\
\hline \multicolumn{7}{|c|}{$2^{\text {nd }}$ subsample } \\
\hline$h_{11}$ & 119 & 306 & 547 & 273 & 197 & 341 \\
\hline$h_{12}$ & 142 & 293 & 443 & 272 & 189 & 12 \\
\hline$h_{22}$ & 219 & 184 & 194 & 195 & 117 & 32 \\
\hline \multicolumn{7}{|c|}{ Panel C: Twin Towers } \\
\hline & Canada & France & Germany & Italy & Japan & $U K$ \\
\hline \multicolumn{7}{|c|}{$1^{\text {st }}$ subsample } \\
\hline$h_{11}$ & 138 & 10 & 8 & 35 & 41 & 13 \\
\hline$h_{12}$ & 135 & 8 & 73 & 35 & 23 & 18 \\
\hline$h_{22}$ & 91 & 62 & 60 & 70 & 65 & 48 \\
\hline \multicolumn{7}{|c|}{$2^{\text {nd }}$ subsample } \\
\hline$h_{11}$ & 385 & 305 & 496 & 89 & 181 & 18 \\
\hline$h_{12}$ & 395 & 292 & 443 & 115 & 124 & 14 \\
\hline$h_{22}$ & 219 & 184 & 194 & 195 & 97 & 21 \\
\hline
\end{tabular}

Notes: Initial Amplification Shock is deducted. Half-life is expressed in days. 
Figure 1: Daily Stock Market Returns
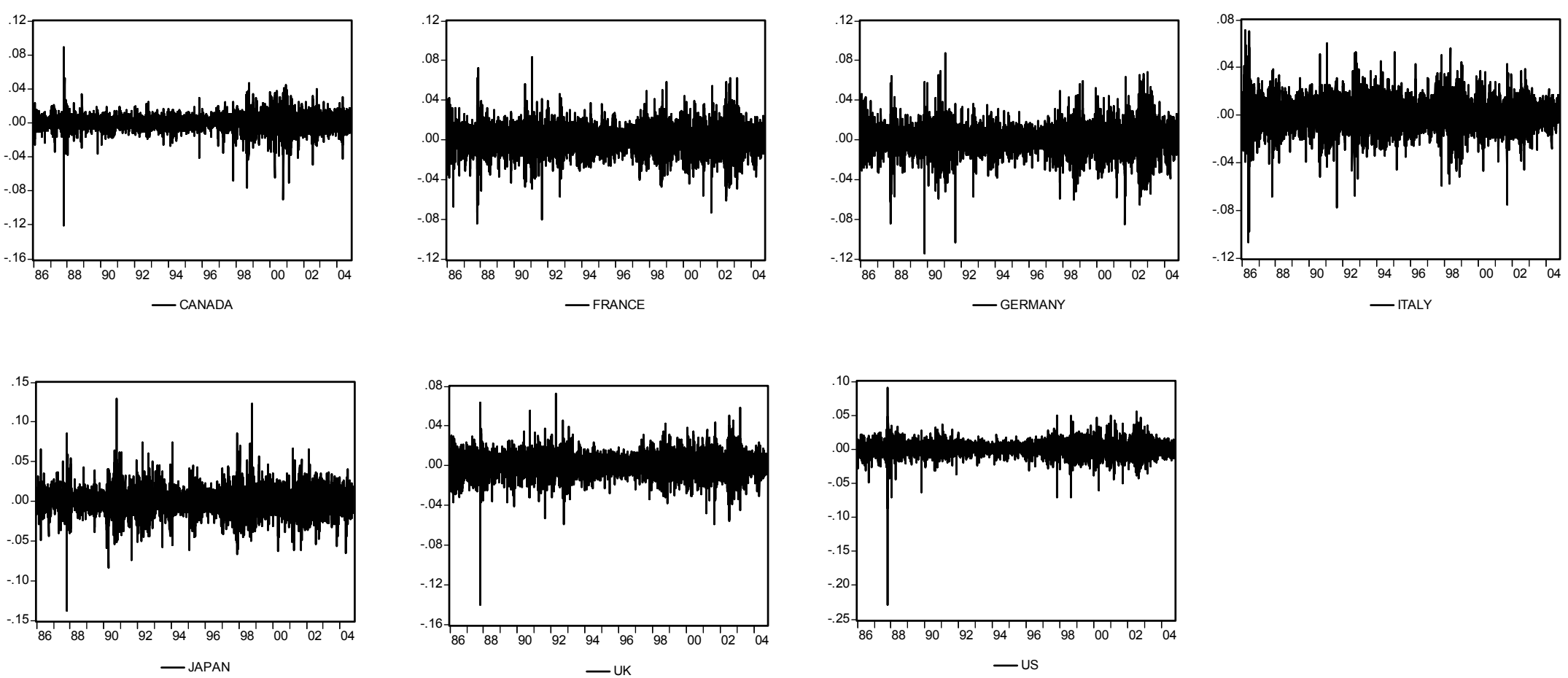
Figure 2: Volatility Impulse Responses (Crash 1987)
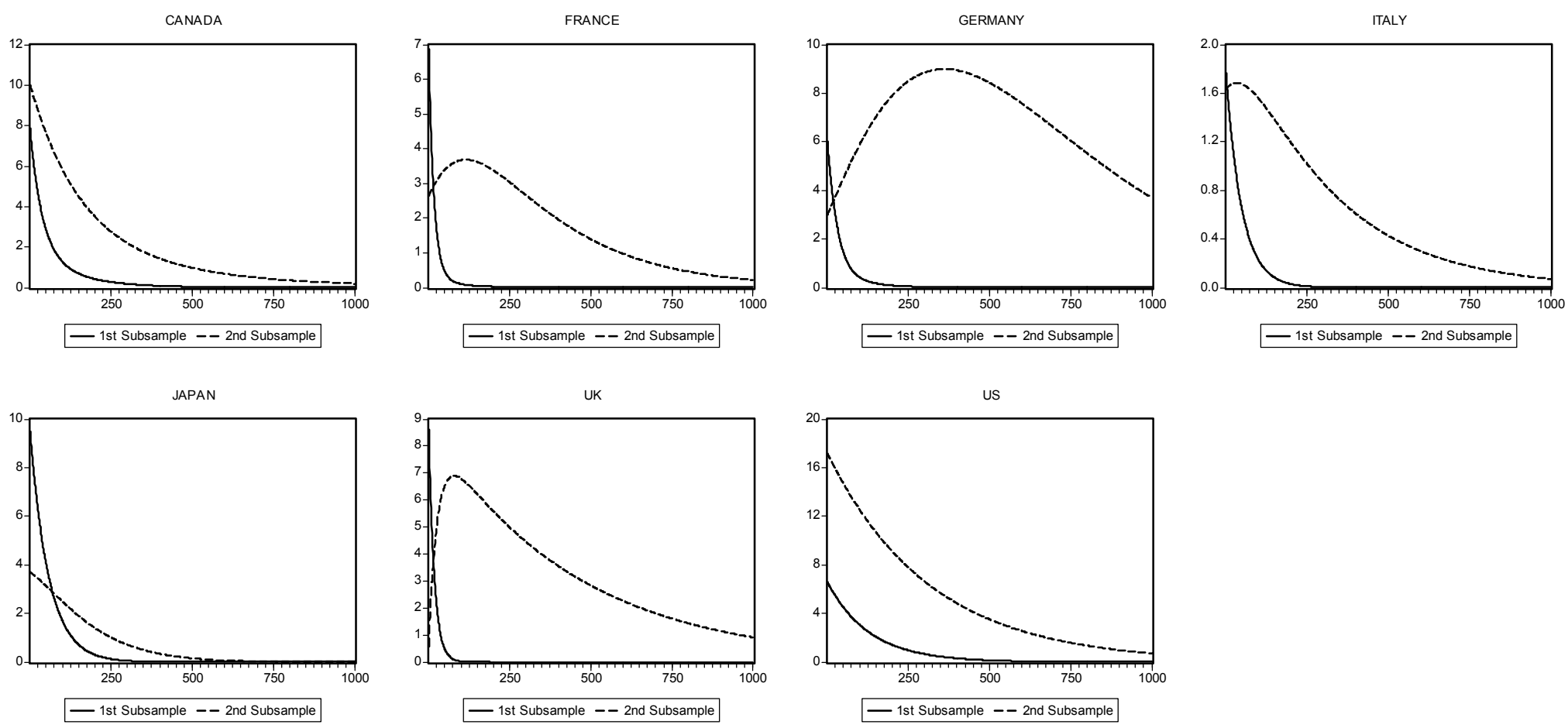
Figure 3: Volatility Impulse Responses (Asian Crisis)
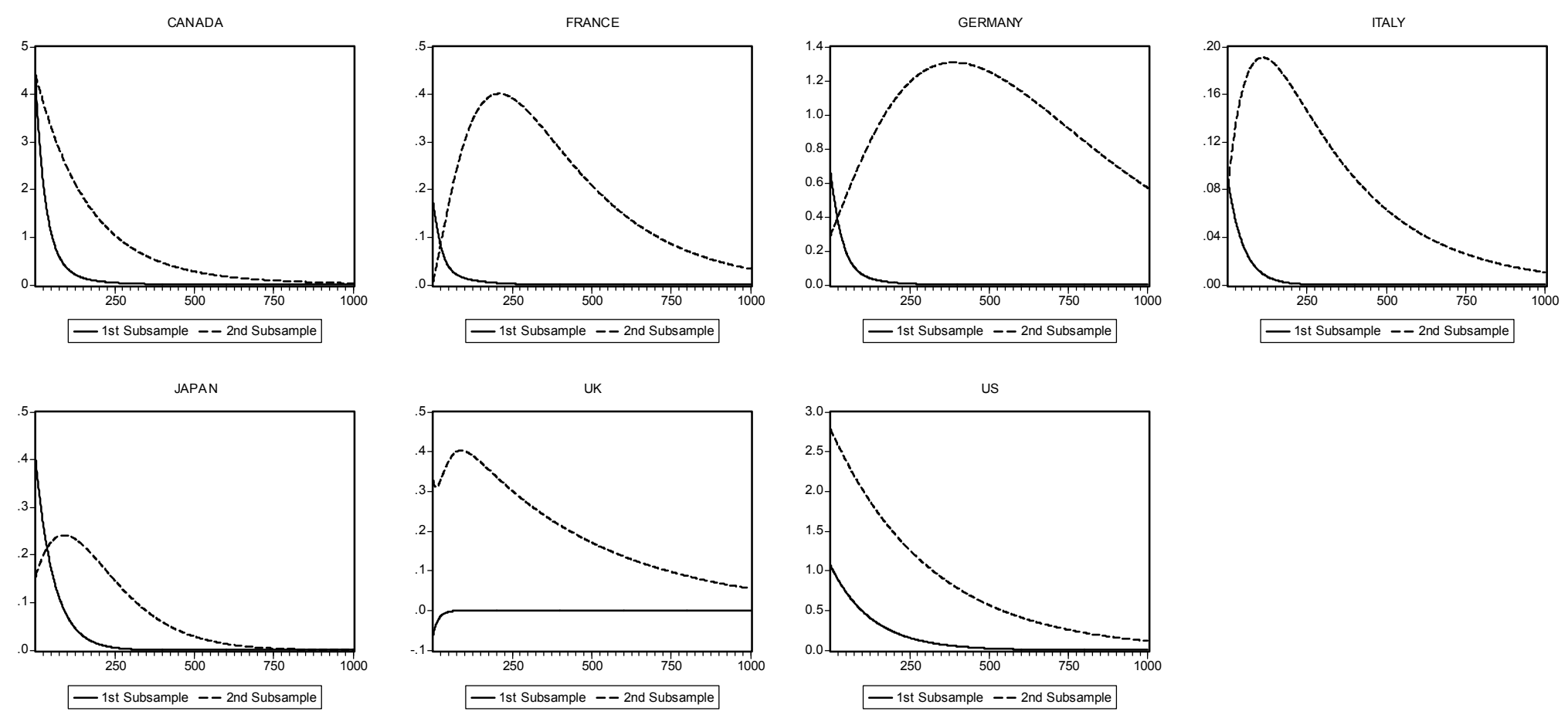
Figure 4: Volatility Impulse Responses (Twin Towers)
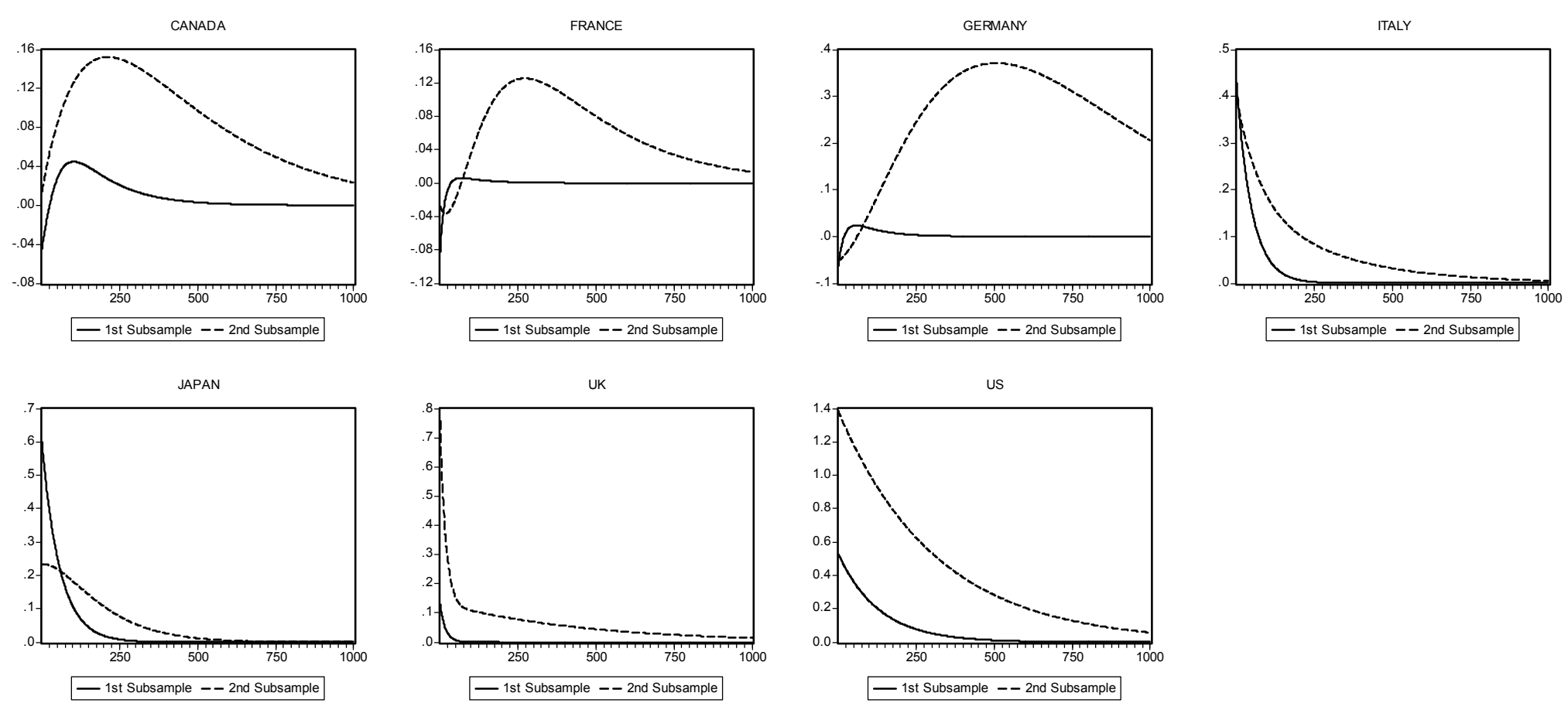